Article

\title{
Late-Spring Severe Blizzard Events over Eastern Romania: A Conceptual Model of Development
}

\author{
Mihaela Caian ${ }^{1}$ and Meda Daniela Andrei ${ }^{1,2, *}$ \\ 1 Weather Forecasting National Center, National Meteorological Administration, Bucuresti-Ploiesti Ave., \\ No. 97, 013686 Bucharest, Romania; mihaela.caian@gmail.com \\ 2 Faculty of Physics, University of Bucharest, P.O. Box MG 11 Magurele, 077125 Bucharest, Romania \\ * Correspondence: meda.georgescu@gmail.com
}

Received: 5 November 2019; Accepted: 27 November 2019; Published: 3 December 2019

\begin{abstract}
In this paper, the mechanism and model-representation of a late-spring severe blizzard event on eastern Romania are studied. The mechanism relies on the coupled contribution of the tropospheric ageostrophic circulations associated to jet streaks. These circulations: (1) interact under local and regional forcing (sea surface temperature, topography and latent heat) and (2) feedback on enhancing an upper-level jet's secondary streak, leading to a persistent, severe event. The enhanced secondary jet streak appears only for developing systems that lead to extreme impact, as shown by 40 years of knowledge of late-spring severe blizzards over the area. It is shown that actual regional high-resolution models are able to represent the occurrence and the mechanism of late-spring severe blizzard events, thus increasing the confidence on their ability to represent current and future climate extreme variability. Understanding the preconditioning of dynamic and thermodynamic processes indicated by this analysis could be useful in supporting the operational forecast analysis.
\end{abstract}

Keywords: blizzard; severe event; jet streak; conceptual model; climatology

\section{Introduction}

Severe weather events (e.g., heavy rainfall, intense wind, blizzard) occurring in eastern and southeastern Romania are often associated with extratropical cyclones over western Black Sea, generally of Mediterranean origin [1-6].

In the cold season (i.e., October-March), the sea is an important source of heat and water vapor, which help the formation and development of cyclones [7-10]. When a Black Sea cyclone is very intense, and/or when it is in strong contact with a high-pressure field (i.e., of East-European, Azores, or Scandinavian origin), high pressure gradient, and often, temperature gradient is generated. Under these conditions, the wind intensifies in eastern and southeastern Romania. The direction and intensity of this local wind (called "crivăț" in Romanian) depends also on the topography [11,12]. The cold air from northern or northeastern Europe is forced to move between the dynamic dam offered by the Eastern Carpathians and the thermal dam of the Black Sea (Figure 1) [13-16]. If this intense wind is associated with snow and causes the temporary decrease of visibility, the generated phenomenon is classified as a blizzard [17]. 


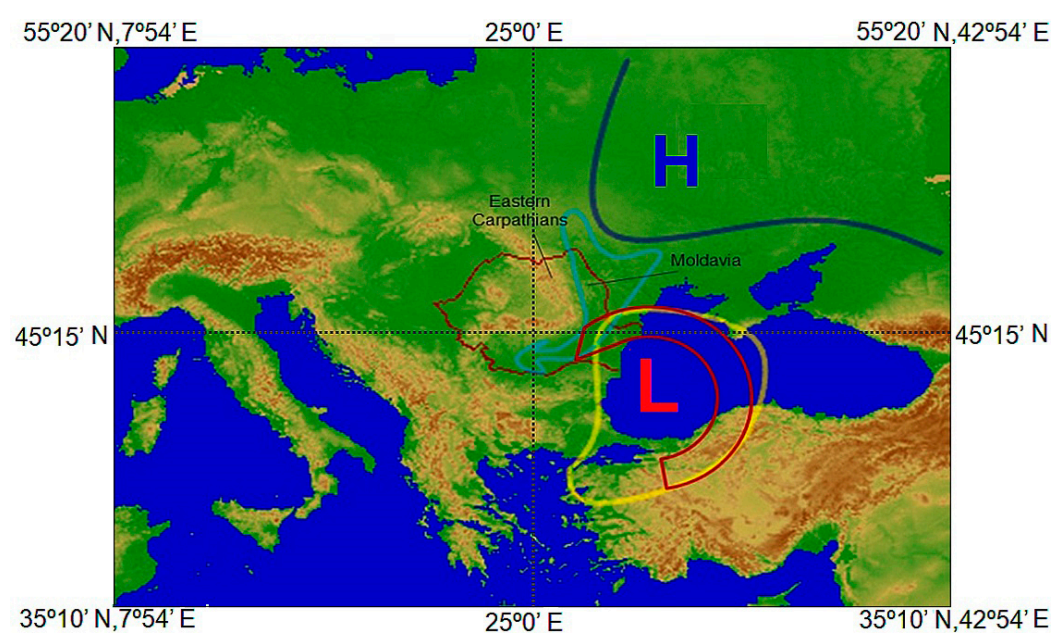

Figure 1. Typical synoptic pattern conductive to blizzard over eastern and southeastern Romania. A low pressure center is present over the Black Sea $(\mathbf{L})$ and high pressure northeast of Romania $(\mathbf{H})$. The cold air advection is indicated by the light blue arrow and the warm air advection by the red arrow. The red contour marks the Romanian territory.

Blizzards are specific to the winter season [18], but can also occur in spring [17]. For example, late-spring occurrences of blizzards were reported on 24 April 1893 in eastern Romania (i.e., Moldavia) and on 28 April 1888 over central Romania (i.e., Transylvania) [19]. In April, blizzards are extremely rare; the monthly average of the number of days with blizzards in eastern and southeastern Romania is between 0 and 0.1 days $[5,19,20]$.

The most recent severe case of a blizzard that occurred during the spring, after more than 20 years, is the blizzard from 19-21 April 2017 over eastern Romania [21]. There were a lot of closed national and county roads because of the heavy snow and intense wind. Due to the intense wind, trees were uprooted and about 300 utility poles were damaged. Under these conditions, hundreds of households were left without electricity. Furthermore, given late occurrence of the blizzard during the year, plants and trees, especially fruit trees, were affected. Therefore, such an event leads to great economic loss and agricultural damages with long-term consequences. The previous similar cyclogenetic event, associated with less damages, occurred on 15-16 April 1996.

The wintertime blizzards over Romania have been intensively studied [22-25] compared with the blizzards that occur in spring $[17,21]$, although late-spring blizzards lead to great agricultural damages and cause economic losses.

Moreover, as the spring progresses, the surface conditions change, as well as sea-atmosphere heat exchange. The sea gets colder than the land, influencing the cyclogenetic potential over the region. However, there are situations when cyclones still develop in late spring over the sea, as recently happened on 19-21 April 2017. This is mainly due to large-scale tropospheric processes, such as the transport of warm and moist air from southern latitudes, as the Mediterranean Sea is often in interaction with the jet stream dynamics [26] and with local or regional forcing. Studies that have highlighted the role of synoptic-local scale interaction in amplifying the extreme events were made for Europe and beyond, too. Apart from the influence of the sea surface temperature (e.g., [27,28]), studies have also focused on the role of orography (including the Carpathian mountains) in the distribution and intensity of precipitation [29-31]. Such studies are important in identifying how atmospheric dynamical and thermodynamical processes interact with the particularities of the topography of each region and, as far as possible, in improving the forecast model output.

The aim of the study was: (1) To investigate the preconditioning and the mechanism of late-spring blizzard occurrence over eastern Romania; (2) to identify characteristic features of this type of blizzard that can be traced in near real-time on observational data; (3) to develop a conceptual model that can 
be used by meteorologists to forecast these type of events and to mitigate their impact; and (4) to assess the modeling ability in reproducing the occurrence and mechanism of such events.

The present paper is organized into five sections. Section 2 presents the data and methods used for late-spring blizzard case study and event climatology analysis. The results of the 19-22 April 2017 case study analysis are discussed in Section 3, which is organized in two sub-sections. The first one presents the observed synoptic context of the event, and in the second one, a set of numerical model sensitivity simulations are conducted to identify the large and regional scale contributing factors. Section 4 analyzes the mechanism of the event and its validation for an event climatology data basis over 40 years for the same region. This chapter is split in two: The first part is dedicated to the description of the proposed conceptual model and the second one to its validation. The conclusions are drawn in the last section.

\section{Data and Methods}

For the synoptic situation were used observational data recorded at the weather stations provided by the Romanian National Meteorological Administration, Meteosat 10-RGB Composites Air Mass satellite image, ERA-Interim reanalysis with $0.75^{\circ} \times 0.75^{\circ}$ horizontal resolution [32], and ECMWF numerical weather prediction model products (obtained using ePort, a product of EUMeTrain project (http://eumetrain.org/eport.html).

Sensitivity numerical experiments (Table 1) were made using a high resolution, non-hydrostatic regional climate model, RegCM4.5 (MM5: Mesoscale Model version 5 of the Penn State/NCAR dynamical core) [33,34]. The model horizontal resolution is $15 \mathrm{~km}$ and has $23 \sigma$-coordinate vertical levels. Physical parametrizations are described in detail by Elguindi et al. [34]. The integration domain and orography of the model are presented in Figure 2 and the initial and lateral boundary conditions were taken from the ERA-Interim $\left(0.75^{\circ} \times 0.75^{\circ}\right)$. The simulation was initialized at $00 \mathrm{UTC}$ on 20 April 2017.

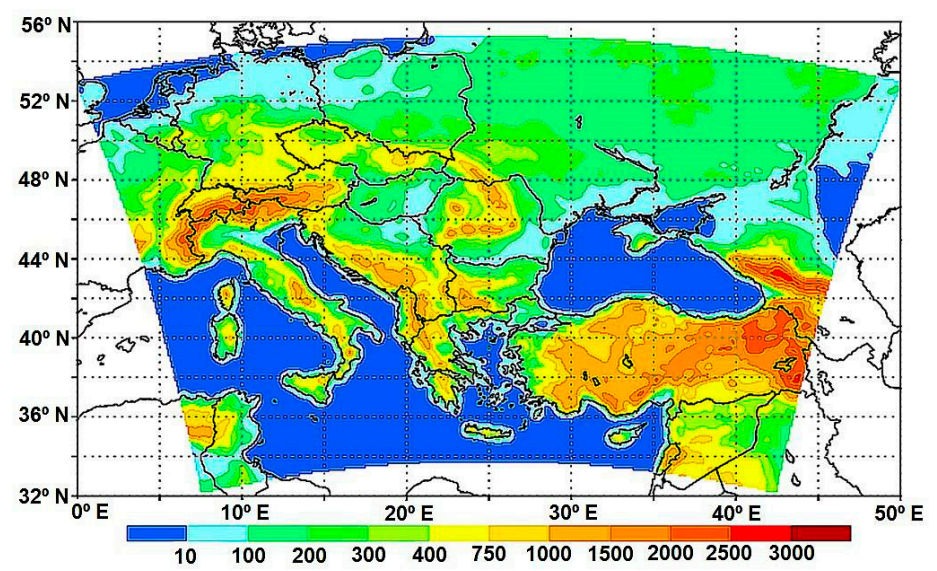

Figure 2. RegCM4.5 model domain and orography (meters as indicated on the color bar): $\Delta x=15 \mathrm{~km}$, Lambert conform projection.

The control experiment was performed with full physics and unmodified initial conditions (CTRL), which provides a basis for comparison.

The main triggers investigated here are schematically presented in Table 1: (1) large-scale: The upper-level jet (ULJ) and the humidity advection (q adv); (2) interaction between large and regional scale (low-level jets (LLJs)); and (3) regional scale: The presence of the sea, sea surface temperature (SST), topography (TOPO), and condensational heat (COND).

Under given atmospheric large-scale forcing, we performed sensitivity numerical simulations to quantify the role of regional forcing on the genesis and development of the event, an approach in similarity with other studies [35-41]. 
Sensitivity simulations (Table 1) were made for: (1) The presence of the Black Sea, experiment NOSEA in which the Black Sea was replaced with soil having the characteristics of the area near the Black Sea shore; (2) the sea surface temperature, experiment SST+4K (Black Sea and Mediterranean Sea SST increased by $4 \mathrm{~K}$ ); (3) the topography, experiment NOTOPO (its altitude was reduced to $200 \mathrm{~m}$ for values higher than this threshold inside the Central domain $\left(\left[43^{\circ} 37^{\prime} \mathrm{N}-48^{\circ} 14^{\prime} \mathrm{N}, 20^{\circ} 17^{\prime} \mathrm{E}-29^{\circ} 39^{\prime} \mathrm{E}\right]\right)$; and (4) an experiment which does not allow condensation and surface latent heat fluxes in the domain, NOCOND.

Table 1. Description of the sensitivity simulations. The star represents triggering elements of the mechanism analyzed.

\begin{tabular}{|c|c|c|}
\hline Scale & \multicolumn{2}{|c|}{ Triggers } \\
\hline Large Scale & \multicolumn{2}{|c|}{$\begin{array}{c}* \text { upper-level jet (ULJ) } \\
* \text { moisture advection (q adv) }\end{array}$} \\
\hline $\begin{array}{l}\text { Large-Regional Scale } \\
\text { Interactions }\end{array}$ & \multicolumn{2}{|c|}{$\begin{array}{c}{ }^{*} \text { low-level jets (LLJs): southerly (linked to indirect ageostrophic circulation } \\
\begin{array}{c}\text { (IC) and q adv); northerly (linked to direct ageostrophic circulation (DC) and } \\
\text { topography) } \\
\text { * baroclinicity } \\
\text { * ageostrophic circulations }\end{array}\end{array}$} \\
\hline \multirow[b]{2}{*}{ Regional Scale } & Regional Triggers & $\begin{array}{l}\text { Sensitivity Numerical } \\
\text { Experiment }\end{array}$ \\
\hline & $\begin{array}{c}* \text { Black Sea } \\
* \text { sea surface temperature (SST) anomaly } \\
* \text { topography } \\
* \text { condensation }\end{array}$ & $\begin{array}{l}\text { experiment: NOSEA } \\
\text { experiment: SST }+4 \mathrm{k} \\
\text { experiment: NOTOPO } \\
\text { experiment: NOCOND }\end{array}$ \\
\hline
\end{tabular}

In this study, we also analyzed the characteristics of late-spring events over the last 40 years for the same region. We selected events from the ERA-Interim database between 1980 and 2019, targeted over east and southeastern Romania. For this, April cases were selected with a cyclone core over the western Black Sea basin (central pressure equal or less than $1015 \mathrm{hPa}$ ) and a cold thermal advection over Romania (at the level of $850 \mathrm{hPa}$, the $-5{ }^{\circ} \mathrm{C}$ isotherm located anywhere above the country). ERA-Interim data performance in representing cold surge statistics was indicated in previous studies $[42,43]$. Severity of impact was accounted for from wind intensity and amount of precipitation data from bulletins archived at the Romanian Meteorological Service. This event data basis was used to validate that the main elements of the proposed mechanism are robust signals for this type of weather events.

\section{Results-Case Study}

\subsection{Observed Synoptic Context}

The blizzard produced in eastern Romania around 20 April 2017 was extreme, especially due to the devastating effects on the vegetation, its occurrence taking place in the second half of the spring. In this case, the wind gusts generally reached speeds of $60-70 \mathrm{~km} \mathrm{~h}^{-1}$ and the abundant snowfall led to the deposition of a wet consistent snow cover in most parts of Moldavia (up to $59 \mathrm{~cm}$ thick at meteorological stations; Figure 3). Some weather stations recorded the largest snow cover of the winter season that ended [21]. 


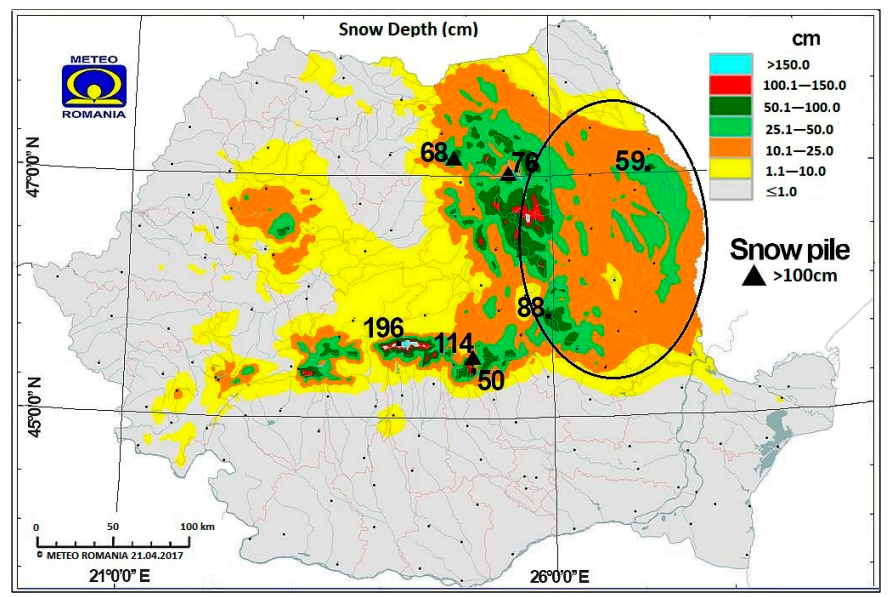

Figure 3. Snow cover (cm) at 06 UTC on 21 April 2017. The black circle marks the area in Moldavia with the largest snow layer. The dots represent the location of the Romanian National Meteorological Administration (NMA) stations. (Copyright NMA).

The cyclone studied in this article originated over the Gulf of Genoa-Mediterranean Sea. Between 17 and 18 April 2017, the cyclone crossed the Balkan Peninsula and at 00 UTC on 20 April, it reached the southwestern Black Sea. For almost $42 \mathrm{~h}$, the cyclone moved northwards, along the western Black Sea, towards the Azov Sea. All this time, the cyclone deepened and on the eastern part of Romania, it produced a strong blizzard, with the maximum intensity (regarding pressure, precipitation and wind strength) between 12 UTC 20 April and 06 UTC 21 April. The mature stage was reached between 21 UTC 20 April and 00 UTC 21 April (Figure 4), when the cyclone's central pressure dropped to almost $1004 \mathrm{hPa}$. After that, it followed a path towards the Azov Sea, and gradually occluded. During this time, the rest of the continent was generally in a high-pressure field. Thus, especially the eastern Romania area was at the contact area between this vast anticyclonic area (to the west and to the north), and the cyclone of Mediterranean origin (to the southeast and east). These resulted in: (1) A strong pressure in the eastern and southeastern parts of the country (of about $1 \mathrm{hPa} / 30 \mathrm{~km}$ (Figure 4), which favored a fast transport of a very cold Arctic air, unusual for April, to southern latitudes (in almost all of Romania, the air temperature at $850 \mathrm{hPa}$ level dropped below $-6^{\circ} \mathrm{C}$, (Figure $4 \mathrm{~b}$ )); and (2) warm and moisture advection associated with the advance of the Mediterranean cyclone, as parts of the thermodynamic elements of the synoptic forcing.

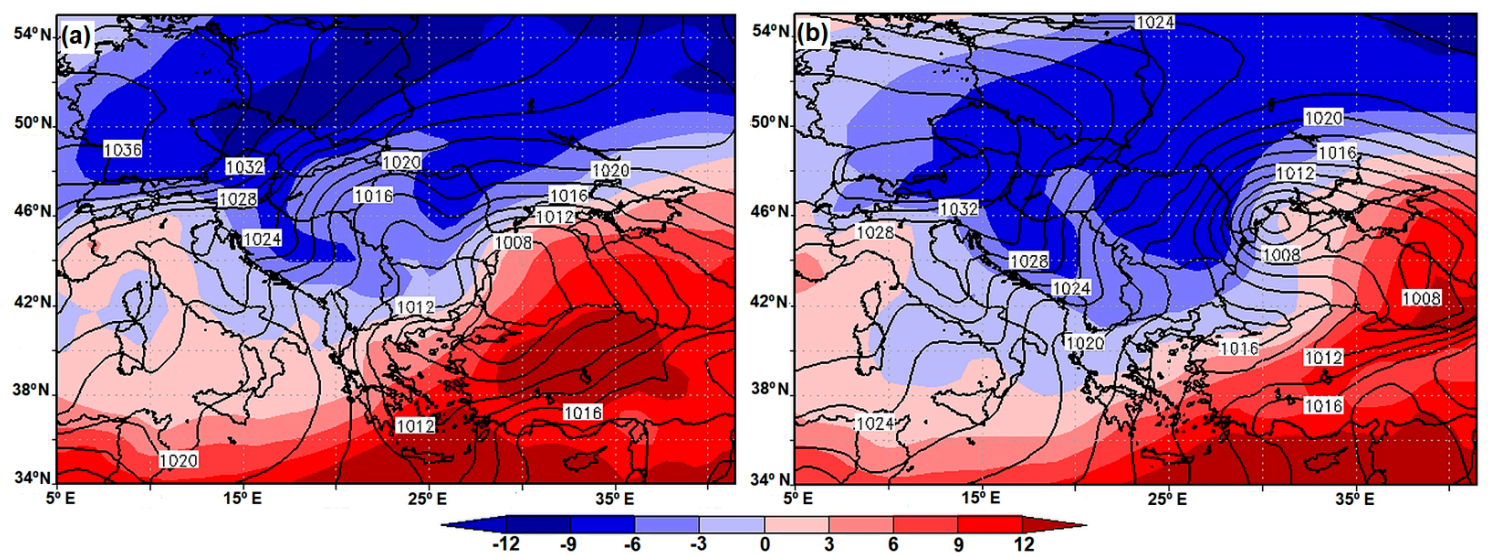

Figure 4. Mean sea level pressure (hPa) (black isobars, every $2 \mathrm{hPa}$ ) and $850 \mathrm{hPa}$ temperature $\left({ }^{\circ} \mathrm{C}\right)$, (shaded as indicated on the color bar, every $3{ }^{\circ} \mathrm{C}$ ), for (a) 12 UTC 20 April 2017 and (b) 00 UTC 21 April 2017 (ERA-Interim data). 
At upper levels, Romania was under the influence of a baroclinically unstable polar jet, with Rossby wave breaking under interaction with a positive potential vorticity (PV) anomaly, moving from the Mediterranean to the Black Sea (Figure 5). Moreover, a tropopause fold can be identified in Figures 6 and $7 \mathrm{a}$, above the area where the low-level cyclone developed. The upward movements generated east of the tropopause folding, and at the left exit of the jet streak played an important role in the amplification of the low-level cyclone, as will be shown below (Figure 7).

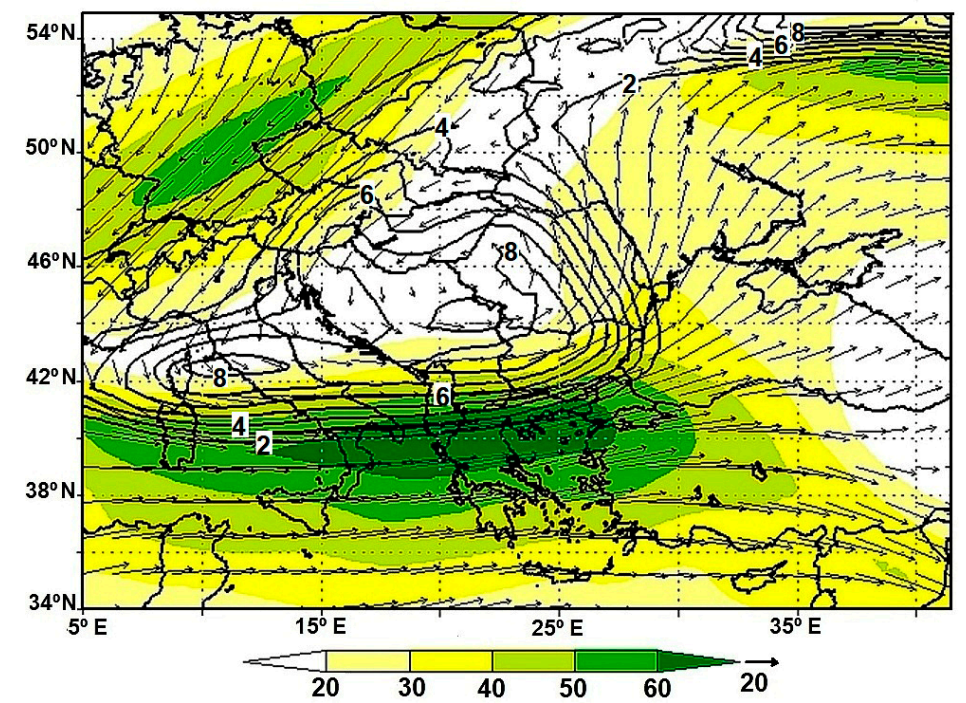

Figure 5. $300 \mathrm{hPa}$ potential vorticity (PVU), (contour every $2 \mathrm{PVU}$ ) and wind at $300 \mathrm{hPa}(\mathrm{m} / \mathrm{s}$ ) (vectors and shaded magnitude as indicated on the color bar) at 12 UTC 20 April 2017 (ERA-Interim data).

A very useful "tool" to identify cyclogenesis is RGB Air Mass satellite image. This is because, by enhancing temperature and moisture characteristics of air masses, it offers the possibility of quick and easy identification of the jet stream (transition zone from blue to red colors along the frontal cloudiness), and the descending stratospheric air with high potential vorticity (reddish color) (Figure 6) [44].

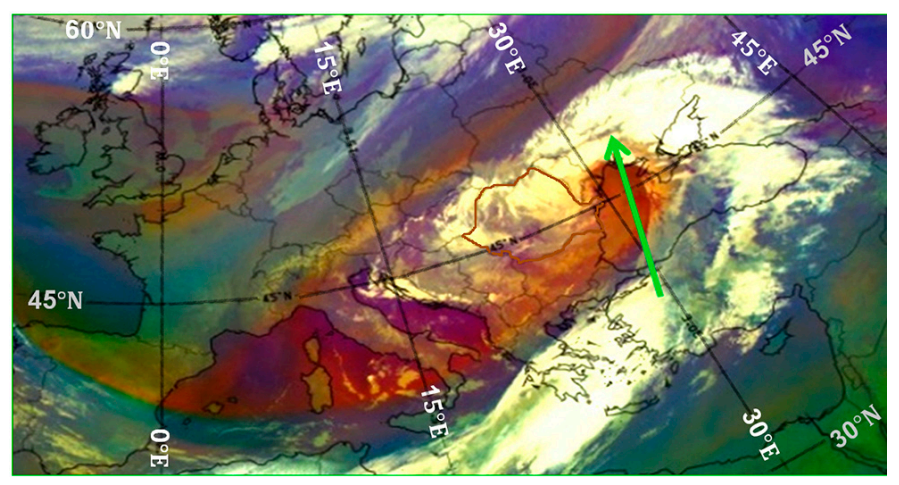

Figure 6. Air Mass RGB (METEOSAT 10) at 00 UTC 21 April 2017 (copyright 2017 EUMETSAT). The green arrow is for the vertical section of Figure 7. (EUMETSAT: the European Organization for the Exploitation of Meteorological Satellites).

The coupling between the lower and the upper layers of the troposphere can be seen in the vertical sections of Figure 7. We note in Figure 7a, a tropopause folding with high PV anomaly at about $43.5^{\circ} \mathrm{N}$ down to 500-600 hPa and two lobe-like downward extensions at $39.5^{\circ} \mathrm{N}$ (L1, associated with the main fold, F1) and at $47^{\circ} \mathrm{N}$ (L2), both also noticed as downward extensions of higher equivalent potential temperature and dryer air, with the area of descending cold air centered about $43.5^{\circ} \mathrm{N}$ (Figures 4 and 7a). 
The main lobe (L1) descending to about $700 \mathrm{hPa}$ appears to be associated with the ULJ shear instability. The second one (L2) appears associated with the interaction between the induced baroclinic area (B) and the tropopause's secondary minor fold (F2), caused by tropopause upwards displacement in the warm area. This interaction was studied in earlier works [45-48], where PV anomaly in the warm sector of a well-developed baroclinic area develops through cold advection by folded tropopause, enhancing this fold. Here, this interaction involves lower levels a high PV that extend from near-surface upwards in the warm sector (Figure 7a), in an escalator-type anomaly (seen from surface at $42^{\circ} \mathrm{N}$ up to $700 \mathrm{hPa}$ at $47^{\circ} \mathrm{N}$ in Figure $7 \mathrm{a}$ and upwards, in the positive vertical velocity about $47^{\circ} \mathrm{N}$ in Figure $7 \mathrm{c}$ ). Consequently, a secondary jet formation (N-ULJ) can be seen in Figure $7 \mathrm{~b}\left(46^{\circ} \mathrm{N}\right)$, corresponding to this surface-upper-level coupling. This low-level PV is related to the surface low advancement (about $46.5^{\circ} \mathrm{N}$ ) and its enhancement when approaching the right exit proximity of the ULJ.

The two lobes of tropopause folding create two thermal-humidity frontal lines that enhance the inner-area cyclonicity (centered $43.5^{\circ} \mathrm{N}$ ). Conversely, the ageostrophic responses to the upper-level jet streaks (ULJ and N-ULJ) are expected to feedback through their downward branches (descent seen in the positive omega at $43.5^{\circ} \mathrm{N}$ and $47.5^{\circ} \mathrm{N}$; Figure $7 \mathrm{c}$ ) and enhance the LLJs, and eventually couple and strengthen the upward circulation, as will be further discussed in Section 3.2. This dynamical feedback at $46^{\circ} \mathrm{N}$-north of $48^{\circ} \mathrm{N}$ appears as a main enhancement element that led to the severe event on eastern Romania. 

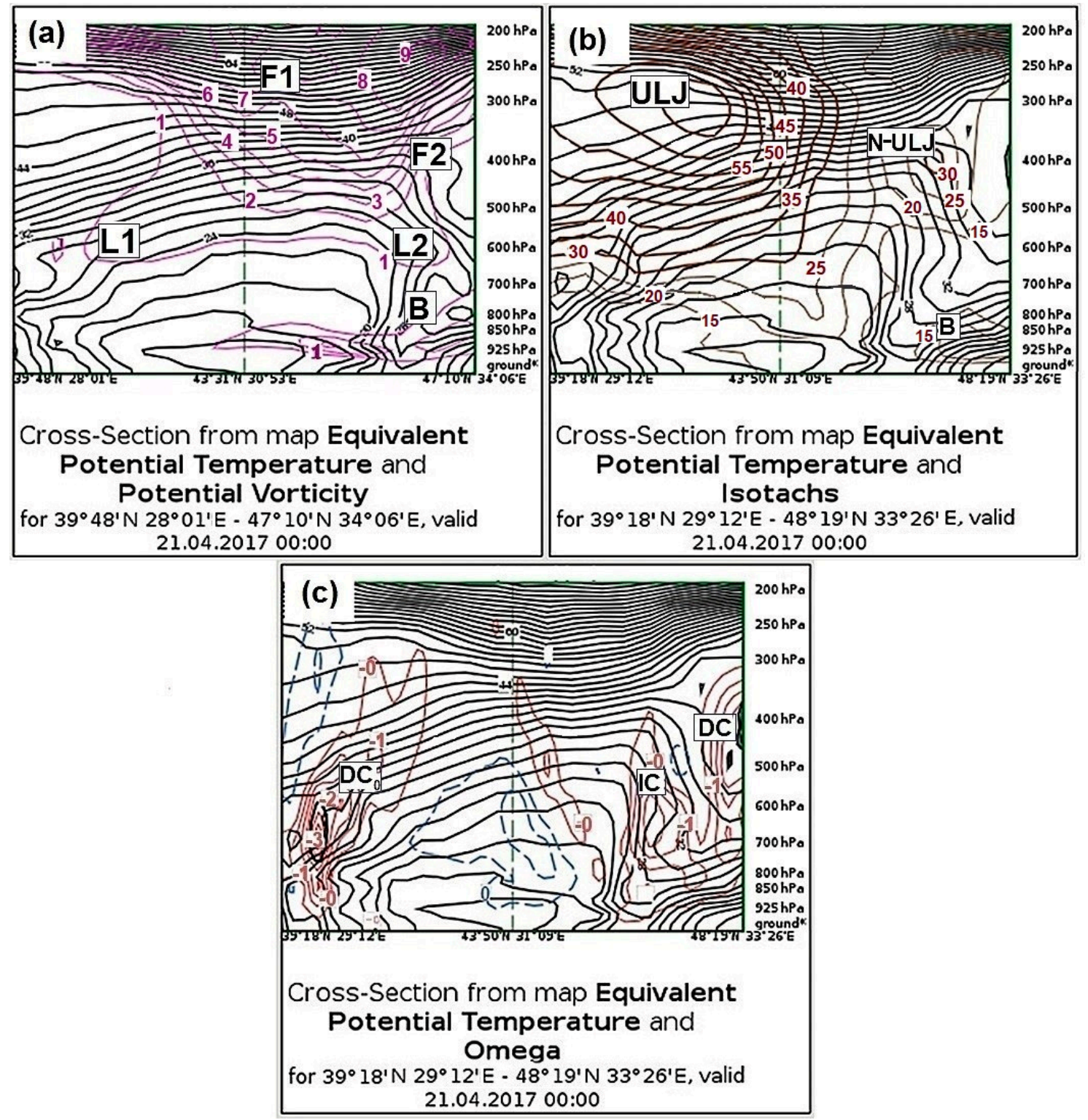

Figure 7. Vertical cross-section in the direction of the green arrow from the Figure 6 at 00 UTC 21 April 2017: (a) PV (pink lines, (PVU)), L1, L2: the two PV lobes in the troposphere (see text); F1, F2: tropopause folds (see text); B: lower-troposphere baroclinic area (see text), (b) isotachs $((\mathrm{m} / \mathrm{s})$, interval $5 \mathrm{~m} / \mathrm{s}$, brown line), ULJ: upper level jet's southern (main) streak, N-ULJ: upper level jet's northern (secondary) streak (see text), (c) omega ((Pa/s), interval $1 \mathrm{~Pa} / \mathrm{s}$, red lines—ascending movements, blue line-descending movements). In all images, black lines show equivalent potential temperature (K, interval $2 \mathrm{~K}$ ) (obtained using ePort, EUMeTrain product-copyright EUMETSAT). $\mathrm{DC}_{0}$ is the main tropopause fold; DC and IC are the tropospheric-ageostrophic circulations linked to the two jet streaks. (Note (a) has a slight shift of the vertical section compared to (b) and (c) due to different grids in computing variables.)

\subsection{Numerical Simulations}

We analyze in this subsection how the observed context is represented by model simulations and use sensitivity simulations (Table 1) to investigate regional factors that lead to event amplification.

The Control run (CTR_15 km) captures very well the cyclone life-time during the genesis and development phase (24-30 h after 00 UTC on 20 April, as shown further on) in terms of pressure and 
temperature evolution. Thus it appears to be a good proxy to further study of the mechanism of the development and of its sensitivity to regional forcings.

\subsubsection{Large-Scale Forcing}

The Upper-Level Jet (ULJ)

The unstable ULJ is well captured by the CTRL run (Figure 8a), at 12 UTC on 21 April, with the two jet streaks in the area (S-Jet at $40^{\circ} \mathrm{N}$ and N-ULJ $53^{\circ} \mathrm{N}$ ), as well as the significant advection of cold air from the north and northeast, and of warm and humid air from the Mediterranean and Black Sea (Figures 4 and 9). Regional conditions linked to this streak split are discussed in the following section.

Large-Scale Humidity-Temperature Advection from the Mediterranean Sea

The warm-humid air advected from the Mediterranean Sea (Figure 9a) creates, up to $300 \mathrm{hPa}$, an east-west thermal and humidity gradient, and a strong release of latent heat by condensation (Figure 9b). This baroclinic zone with increased directional vertical wind shear and baroclinic instability extracting available potential energy from the mean-flow supports the polar jet streak break, and the enhancement of the secondary jet streak in the northeast (N-ULJ, $53^{\circ} \mathrm{N}$ ). The role of humidity advection and condensation on the secondary streak enhancement (edge-central area $47^{\circ} \mathrm{N}-51^{\circ} \mathrm{N}$ ) is emphasized in Figure 8a vs. Figure 8b. Without condensation, the N-ULJ has a maximum of $35 \mathrm{~m} / \mathrm{s}$ in the domain (Figure $8 b$ ), against $40 \mathrm{~m} / \mathrm{s}$ as obtained by the CTRL simulation (Figure $8 \mathrm{a}$ ). Another but smaller contribution to the secondary streak enhancement comes from the presence of the Black Sea (Figure 8a,d), that induces stronger westerly wind at all levels north of the Black Sea, from a thermal wind-driven pressure anomaly discussed further in Section 3.2.3. 

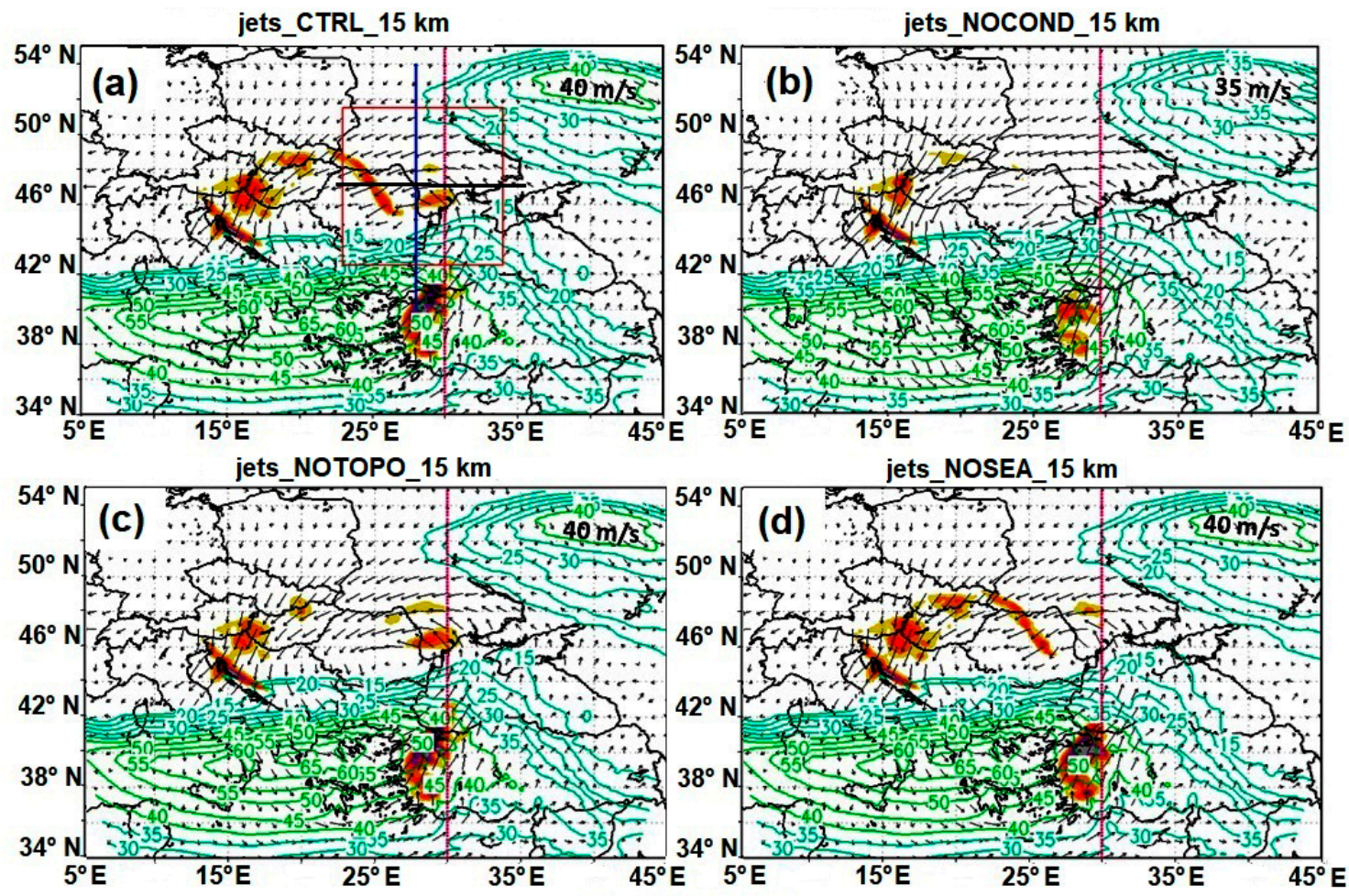

jets_SST+4K_15 km

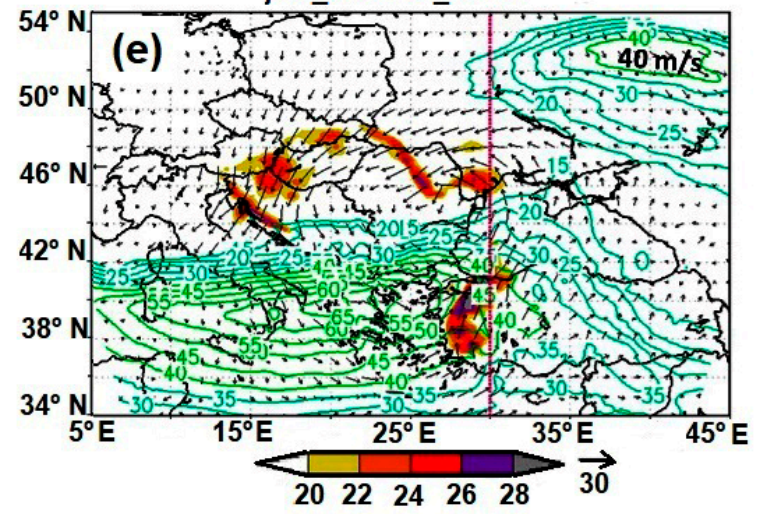

Figure 8. Isotachs at $300 \mathrm{hPa}(\mathrm{m} / \mathrm{s})$ (U wind component), green light lines more than $40 \mathrm{~m} / \mathrm{s}$, and blue light lines less than $40 \mathrm{~m} / \mathrm{s}$ (starting with $15 \mathrm{~m} / \mathrm{s}$, every $5 \mathrm{~m} / \mathrm{s}$ ), $850 \mathrm{hPa}$ wind (vector), LLJs (magnitude $>20 \mathrm{~m} / \mathrm{s}$ - shaded as indicated on the color bar). For: (a) CTRL (Control run, Table 1), (b) NOCOND (simulation without condensation, Table 1), (c) NOTOPO (simulation with topography high reduced below 200 m over Romania, Table 1), (d) NOSEA (simulation without Black Sea, Table 1), (e) SST + 4 K (simulation with sea surface temperature increased by 4K, Table 1), valid at 12 UTC 20 April 2017. In (a): dark blue line-direction of the vertical cross section (see text); red dotted line-landmark for $\mathrm{N}$-ULJ position, indication for the $30^{\circ} \mathrm{E}$; transparent square-area of ageostrophic circulation, andblack line-location of LLJs joint. 
RH + Temperature at $300 \mathrm{hPa}$ CTRL $15 \mathrm{~km}$

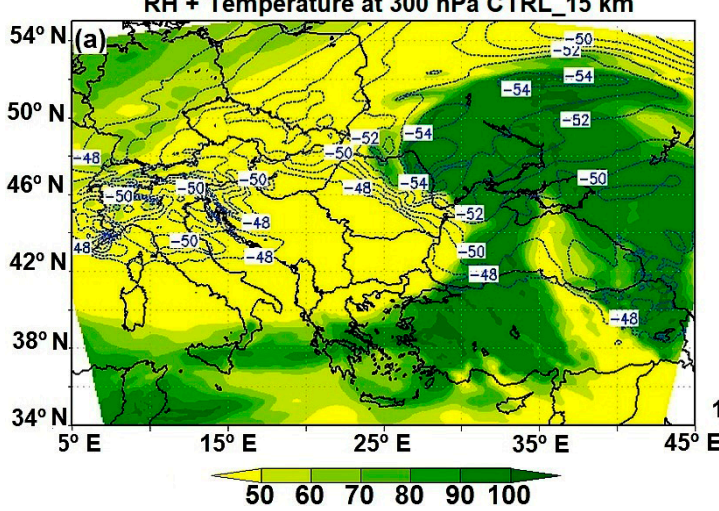

lon=31, U,V,(V,W) CTRL 15 km

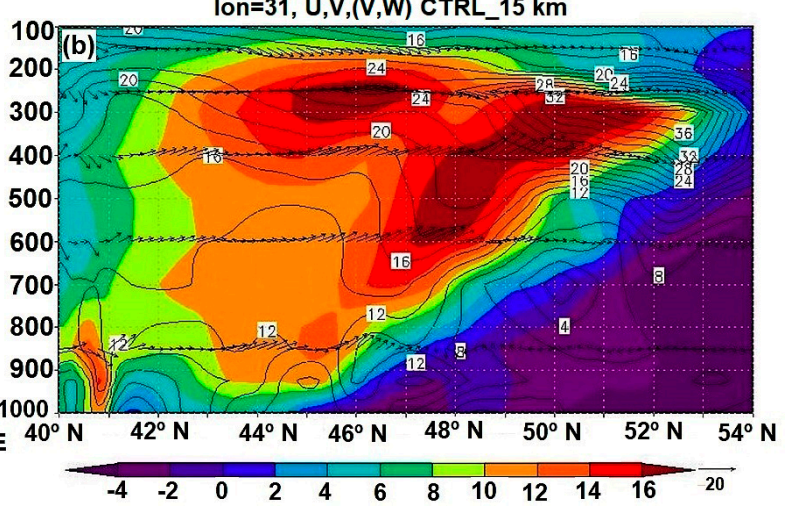

Figure 9. (a) $300 \mathrm{hPa}$ relative humidity (\%) (shaded as indicated on the color bar) and temperature $\left({ }^{\circ} \mathrm{C}\right.$, dotted lines, every $\left.1{ }^{\circ} \mathrm{C}\right)$, CTRL run; Ox axis: latitude; Oy axis: longitude. (b) Upward vertical velocity $((\mathrm{V}, \mathrm{W})$, arrows, $(\mathrm{m} / \mathrm{s}), \mathrm{W}$ was multiplied by 100$)$; horizontal wind magnitude $((\mathrm{m} / \mathrm{s})$, shaded as indicated on the color bar); wind magnitude (m/s), contour each $2 \mathrm{~m} / \mathrm{s}$ in CTRL from 850 to $400 \mathrm{hPa}$ conducting to a mid-level jet (at $600-400 \mathrm{hPa}, 48^{\circ} \mathrm{N}$ ) and a secondary N-ULJ (at $\left.300 \mathrm{hPa}, 51^{\circ} \mathrm{N}\right)-12$ UTC 20 April 2017; Ox axis: latitude; Oy axis: pressure levels (hPa).

\subsubsection{Large-Regional Scale Interaction: An Enhancing Mechanism}

We now further analyze the model's ageostrophic circulations already seen in observations (Figure $7 \mathrm{c}$ ), and investigate the role of the local and regional forcings in their amplification. This amplification has as main sources the enhancement of LLJs, the baroclinicity, and ageostrophic circulation enhancement through coupling.

\section{LLJs (Low-Level Jets)}

In the CTRL run, the formation of two LLJs can be noticed over Romania, corresponding to the indirect (IC) and direct (DC) ageostrophic circulation of the, respectively, S-Jet and N-ULJ streaks (Figure 8), here noted as IC-LLJ and DC-LLJ.

As can be seen from the sensitivity experiments (Table 1) in Figures 8 and 10, the major regional influence on LLJs comes from the condensation process. This enhances at lower levels both LLJs (thermal wind induced by the condensation latent heat; Figure 10a); in particular, the IC-LLJ succeeds to cross the S-Jet in CTRL in Figure 8a, crossing that is not seen in the NOCOND experiment in Figure 8b).

This crossing is an important feature, since it enhances the upward branch of IC, leading to a deeper mean sea level pressure (MSLP) and an accelerated upward branch of the IC (Figure 11b), in opposite to cases when LLJ remains parallel to the jet and the associated circulations damped each-other.

The role of the sea (CTRL-NOSEA experiment) can be seen in Figures $8 \mathrm{~d}$ and 10b. The main response comes from the breeze circulation that strengthens the IC-LLJ along and north of the Black Sea Romanian coast (Figure 8a vs. Figure 8d). The SST anomaly (SST $+4 \mathrm{k}$ versus CTRL) influences are significant on the IC (warmer SST for both the Mediterranean and Black Sea creates stronger thermal coastal gradient), but this also strengthens the DC-LLJ (Figures 8e and 10c) by a farther northward advancement, so it favors a more vertically developed ageostrophic circulation. The way in which local thermo-dynamics (circulation, thermal gradients) are driven by sea and SST is further discussed in the sub-Section 3.2.3.

The role of the topography is important in the lower levels. In Figure 10d, it can be seen first, the decrease of wind intensity in upwind areas in the presence of topography: This is due to divergence associated with higher pressure upwind, but is also modulated by a subcritical Froude flow (colder air at $850 \mathrm{hPa}$ inside the boundary layer; Figure 4) that allows upwind wave propagation. Second, we note anomalous channeling of the wind following the topography curvature of the Carpathians mountains in CTRL-NOTOPO at $850 \mathrm{hPa}$-similar to Coandă-effect $[8,49,50]$, with stronger intensity 
downwind everywhere (Figure 10). This effect is due to increasing Froude above topography reaching super-critical values, hence enhancing conversion of potential to kinetic energy downwind.

Both of these effects enable DC-LLJ convergence towards IC-LLJ (in the area $\left[45^{\circ} \mathrm{N}-47^{\circ} \mathrm{N}\right.$, $\left.28^{\circ} \mathrm{E}-30^{\circ} \mathrm{E}\right]$; Figure $10 \mathrm{~d}$ ) and favor their interaction.

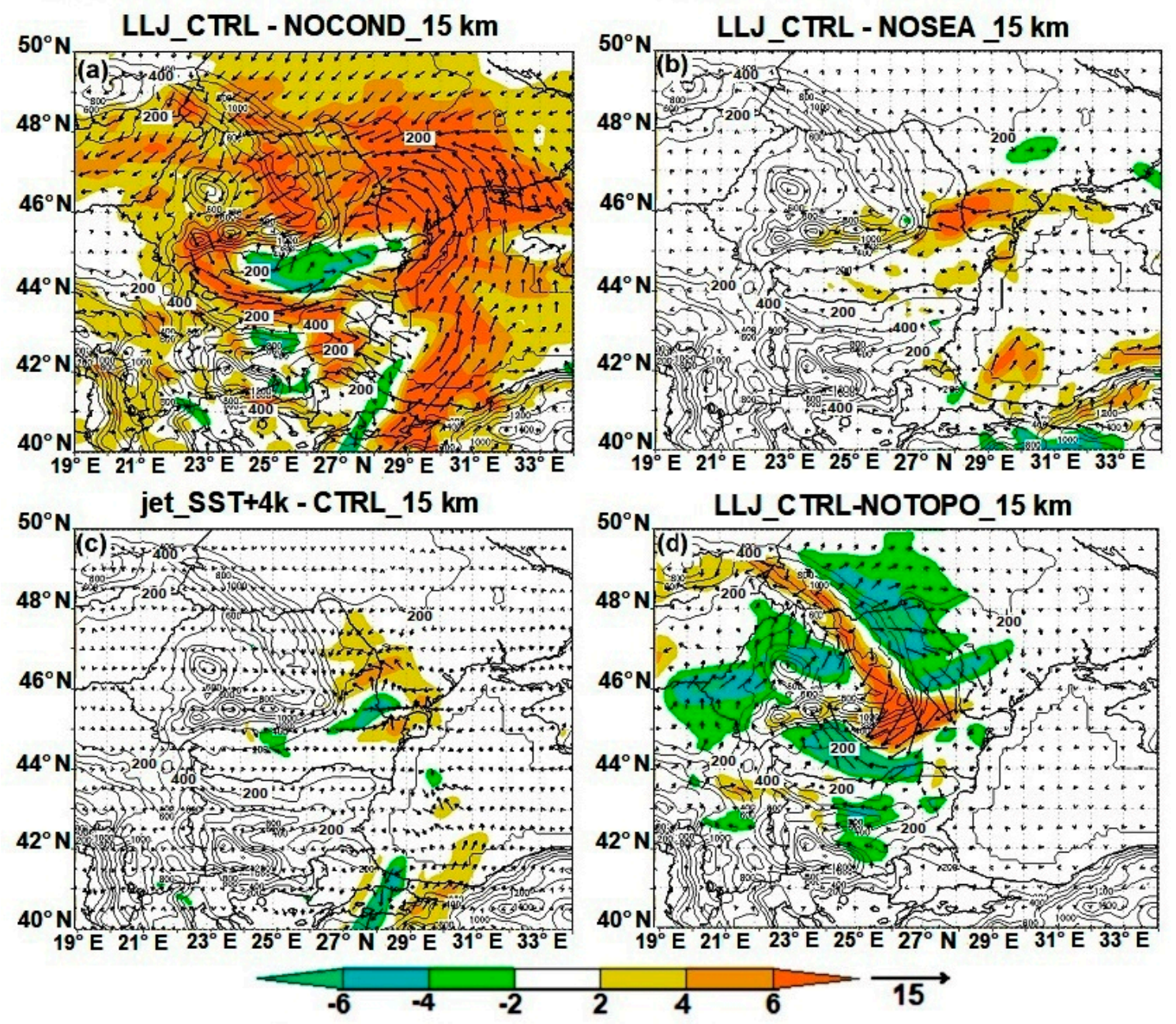

Figure 10. $850 \mathrm{hPa}$ wind differences (vector and magnitude $(\mathrm{m} / \mathrm{s})$ —shaded as indicated on the color bar): (a) CTRL-NOCOND, (b) CTRL-NOSEA, (c) SST + 4 K-CTRL, (d) CTRL-NOTOPO, at 12 UTC 20 April 2017. Black contour is for topography (every $100 \mathrm{~m}$ ).

Baroclinicity and Ageostrophic Circulations

Regarding ageostrophic circulations, indeed Figure 11a shows in the CTRL run a coupling of the indirect circulation (IC) corresponding to the S-Jet streak and the direct one (DC) corresponding to the N-ULJ streak, in agreement with the coupling of observed vertical ageostrophic circulations in Figure 8.

The northward tilted ascent (positive zonal wind from $40^{\circ} \mathrm{N}$ at the surface to about $52^{\circ} \mathrm{N}$ at $300 \mathrm{hPa}$ ), indicates its "escalator" type. The coupling IC-DC is indicated by the same tilt of coupled positive-negative meridional wind with two distinct same-tilted ascent streams-one stream originating south of $40 \mathrm{~N}$ with peaks associated with northwards wind maxima (e.g., at $600 \mathrm{hPa}-43^{\circ} \mathrm{N}$ and at $400 \mathrm{hPa}-45^{\circ} \mathrm{N}$ ), and the second associated with southwards wind (peaks at $900 \mathrm{hPa}-45.5^{\circ} \mathrm{N}$, $600 \mathrm{hPa}-46.5^{\circ} \mathrm{N}$, and at $400 \mathrm{hPa}-47.5^{\circ} \mathrm{N}$ ). Their coupling and mutual enhancement favors the persistence and amplification of the event [26].

Figure 11 intercompares the modulation of these ageostrophic circulations by the regional sources in terms of differences to the CTRL run, induced by the condensation, the topography, the presence 
of the sea, and the sea temperature. Figure $11 \mathrm{~b}$ demonstrates the dominant role of condensation in enhancing both IC and DC. This is seen as a dipolar anomaly in the meridional wind at $400 \mathrm{hPa}$, negative at $46^{\circ} \mathrm{N}$ (enhancing IC), and positive at $50^{\circ} \mathrm{N}$ (enhancing DC), with stronger positive vertical velocity along the upwards branch of the coupled ageostrophic circulation.

The topography has a main role on the low-level DC: Stronger vertical velocity is associated with southwards meridional wind anomaly, mainly below $800 \mathrm{hPa}$ over $\left[46^{\circ} \mathrm{N}-47^{\circ} \mathrm{N}, 28^{\circ} \mathrm{E}\right]$ in Figure 11c. It enhances the lower-level ascent and couples with the IC circulation in the lower levels (tilted anomaly dipole), shifting it southwards. At upper levels, the contribution is small, but still acts to enhance two distinct circulations (dipolar anomaly at $300 \mathrm{hPa}$ ), creating a mean-tropospheric orographic convergence, so surface pressure increases. This increase (found also from PV conservation) creates low-level divergence that enables the IC/DC coupling and could be modulated by the gravity waves in function of the Froude number.

The presence of the Black Sea contributes to enhance the low-level IC: Figure 11d shows stronger vertical velocity associated with northwards meridional wind anomaly (seen also in Figure 10b), from $1000 \mathrm{hPa}\left(44.5^{\circ} \mathrm{N}\right)$ to $700 \mathrm{hPa}\left(46.5^{\circ} \mathrm{N}\right)$. However, the increased ascent is mostly limited to the lower troposphere $(600 \mathrm{hPa}$, with one polar or same-signed anomaly above) and quite barotropic in nature above the boundary layer (stronger ascent aligns about $46.5^{\circ} \mathrm{N}$ in the layer $800-400 \mathrm{hPa}$ ). This is due to the local coastal anomaly forcing, and would eventually damp the upper-level IC and the surface deepening. When a warmer SST is present (Figure 11e), this leads in addition to a stronger and northward advanced IC low-level jet (Figure 8d) with broad warm sector over sea, leading to an enhanced and deeper ascent from $750 \mathrm{hPa}\left(45.5^{\circ} \mathrm{N}\right)$ to $250 \mathrm{hPa}\left(47.5^{\circ} \mathrm{N}\right)$.

The most important contribution to baroclinic instability, favoring persistence and development of the process, would then be expected from condensation processes. 

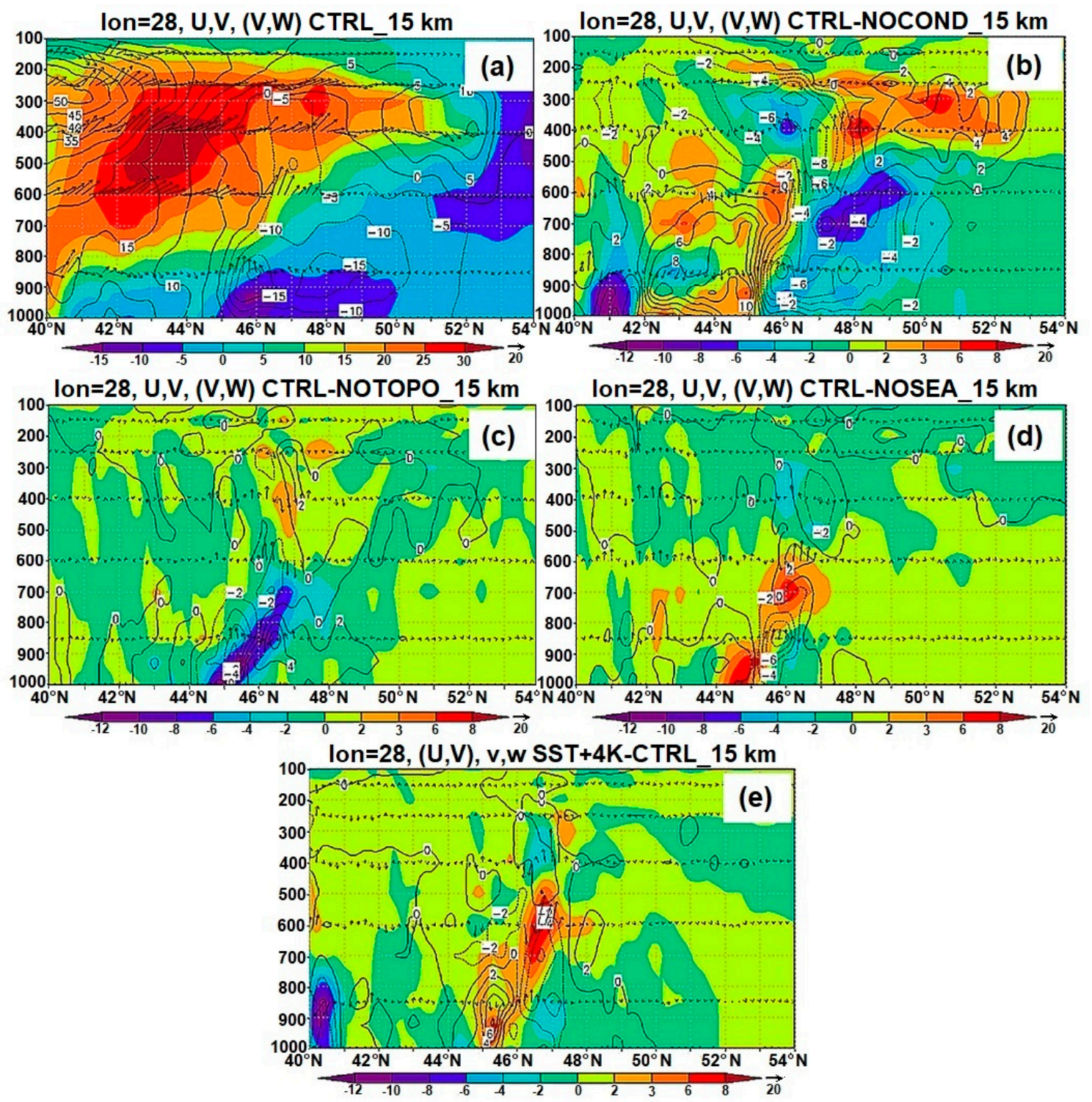

Figure 11. Vertical cross section (along the dark blue line in Figure $8 a)$ : zonal wind $(U \mathrm{U} / \mathrm{s})$, contour lines, interval $2 \mathrm{~m} / \mathrm{s})$, meridional wind $(\mathrm{V}(\mathrm{m} / \mathrm{s})$, shaded as indicated on the color bar), and the ageostrophic circulation $(\mathrm{V}, \mathrm{W})$ (vector, $(\mathrm{m} / \mathrm{s}), \mathrm{W}$ was multiplied by 100$)$ at $28^{\circ} \mathrm{E}$ for the (a) CTRL, (b) CTRL-NOCOND, (c) CTRL-NOTOPO, (d) CTRL-NOSEA, and (e) SST + 4 K-CTRL, for 12 UTC 20 April 2017. Ox axis: latitude; Oy axis: pressure levels (hPa).

\subsubsection{Regional Forcings: Role on Localization and Development of the Event}

The impact of regional forcing and response on the mean sea level pressure (deepening and persistence) and on the location and extent of the precipitation area is further discussed.

\section{Deepening}

The time evolution of the minimum surface pressure in the area $\left[20^{\circ} \mathrm{E}-35^{\circ} \mathrm{E}, 36^{\circ} \mathrm{N}-51^{\circ} \mathrm{N}\right]$ is shown in Figure 12. The first thing to be noticed is that the condensation process has the greatest impact on the deepening of the cyclone, inducing a pressure deepening of $3.5 \mathrm{hPa}$. The other triggers induce smaller differences to CTRL, between 1 and $-1 \mathrm{hPa}$. We note, in particular, the opposing effect of the sea and warmer SST on the deepening. As discussed, a shallow, local development triggered by coastal circulation inhibits deep vertical convergence and surface pressure deepening. Over sea, another 
contribution might be supplied by lower roughness for the pressure increase in CTRL compared to NOSEA.

\section{Persistence}

Baroclinic development and interaction of ageostrophic circulations (IC and DC) were assumed to contribute to the persistence of the development phase. Indeed, we find a longer persistence (Figure 12; as time-length when pressure minima is deeper than CTRL) due to condensation, to a warmer SST and to the presence of topography (under sub-critical Froude flow), that are the factors shown to sustain deep baroclinic circulations up to $250 \mathrm{hPa}$.

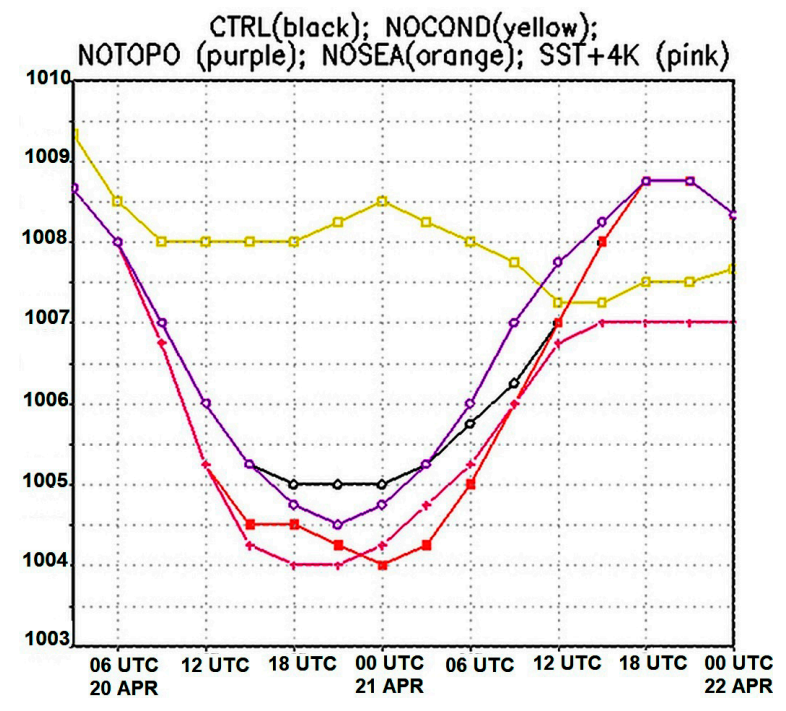

Figure 12. Time evolution (Ox, hours) of mean sea level pressure minima $(\mathrm{Oy}, \mathrm{hPa})$ over $\left[20^{\circ} \mathrm{E}-35^{\circ} \mathrm{E}-\right.$, $36^{\circ} \mathrm{N}-51^{\circ} \mathrm{N}$ ] for each experiment (colors explained in top); note the opposing effect of sea and SST $+4 \mathrm{~K}$ in late-spring winter events (sea: minima damping effect; SST $+4 \mathrm{~K}$ : minima deepening and increased persistence effect); note the increased persistence due to the topography; note the significant deepening and persistence by condensation and surface fluxes.

The weather impact of the regional forcing for the simulated case study is analyzed in the following, in the mean response over $24 \mathrm{~h}$ (between 06 UTC 20 April and 06 UTC 21 April, 2017) leading to departures from the CTRL simulation.

Location and Extent

Sea and SST

The presence of the sea creates, due to coastal circulation, a mean thermal gradient that adds opposing day-night contributions to the large-scale thermal advection. The resulting vector shows a rotation, cyclonic by day and anticyclonic by night, that acts to produce a curved LLJ and makes the low pressure's center be biased towards the southwest or northeast for an actual (Figure 13d) respectively warmer SST (Figure 13e). This feature relates well with the already noticed northwards shift of IC section in Figure 11e for warmer SST. These result in a shift in precipitation towards the southwest/northeast for a colder/warmer SST—compared to CTRL (Figure 14)—and increased amount for warmer SST (deep ascent is enhanced), features that could be a near real-time indicator in forecasting operations. 

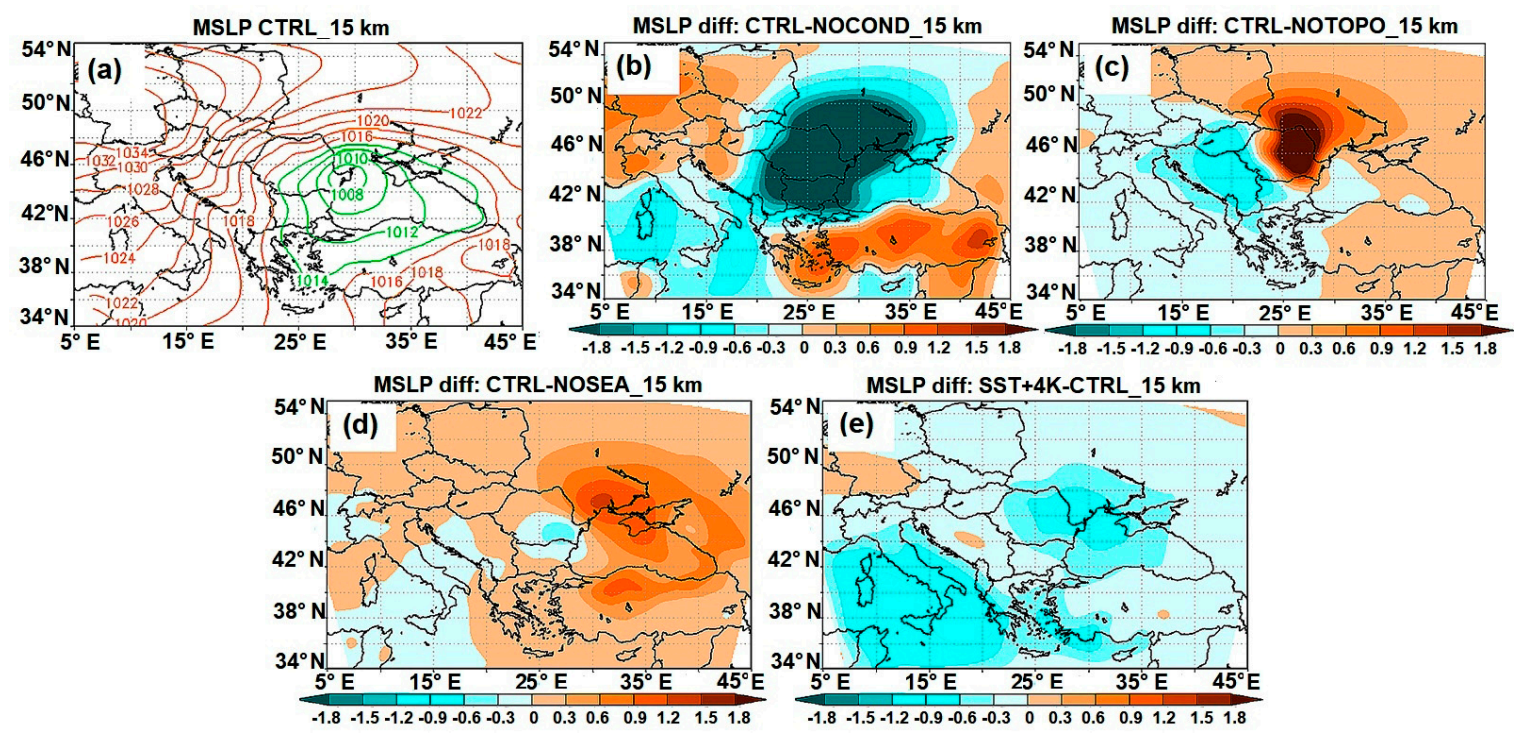

Figure 13. (a) mean sea level pressure mean (hPa) (CTRL, contour interval $2 \mathrm{hPa}$ ); (b-d) the difference in mean sea level pressure mean from each process: (b) CTRL-NOCOND; (c) CTRL-NOTOPO; (d) CTRL-NOSEA; (e) SST+4K-CTRL. The mean is from 06 UTC 20 April to 06 UTC 21 April 2017. All fields are shaded as indicated on the color bar.

\section{Condensation and Surface Fluxes}

The significant contribution of condensation can be seen in Figure 13b. Condensation and latent heat release create a warmer layer and expansion, with increased pressure and divergence above, and lower surface pressure.

Under these conditions, the largest precipitation anomalies associated with condensation processes are in the east-northeast, with an increase of about $25-30 \%$ compared to the NOCOND experiment (Figure 14b).

\section{Topography}

The impact of the topography on MSLP can be observed in Figure 13c. A dipole of anomaly appears in MSLP over the domain, due to the potential vorticity (PV) lee stretching across the mountain chain. Upwind (positive pressure anomaly), there is the area of maximum orographic convergence and precipitation anomaly due to the presence of topography (with less precipitation downstream; Figure 14c).

Consistent with the MSLP dipole, there is a cold/warm anomaly in the upwind/downwind sides (Figure 15a), up to $2^{\circ} \mathrm{C}$ on 24 h average. This enhances the thermal gradient (in Figure 4 ) and presumably the intensity and persistence of the development (seen in Figure 12), compared to NOTOPO.

These result in a significant contribution to the total precipitation (up to $28 \%$, in the area of precipitation maxima-Moldavia; Figure 14c) due to the presence of topography. 

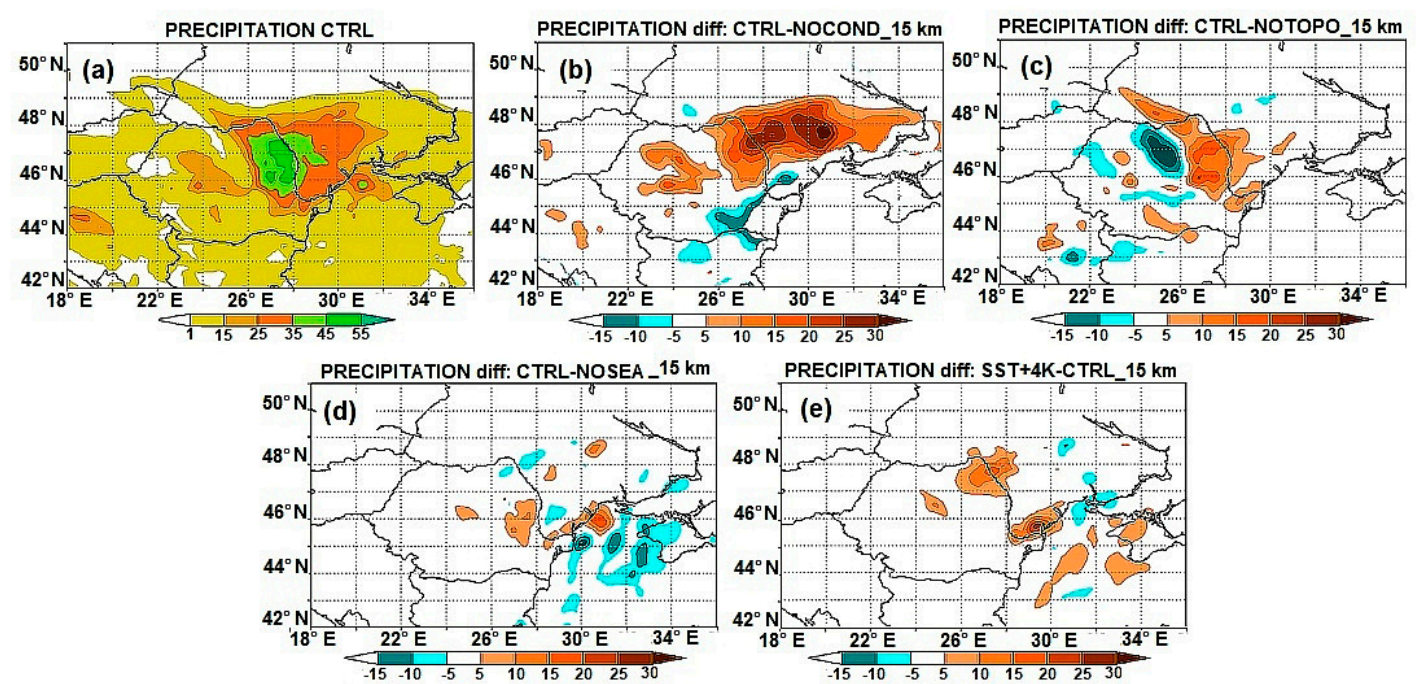

Figure 14. (a) Precipitation (mm) in CTRL averaged from 06 UTC 20 April to 06 UTC 21 April 2017; (b-e) the difference in average precipitation from each process: (b) CTRL-NOCOND; (c) CTRL-NOTOPO; (d) CTRL-NOSEA; (e) SST+4K-CTRL. All fields are shaded as indicated on the color bar.
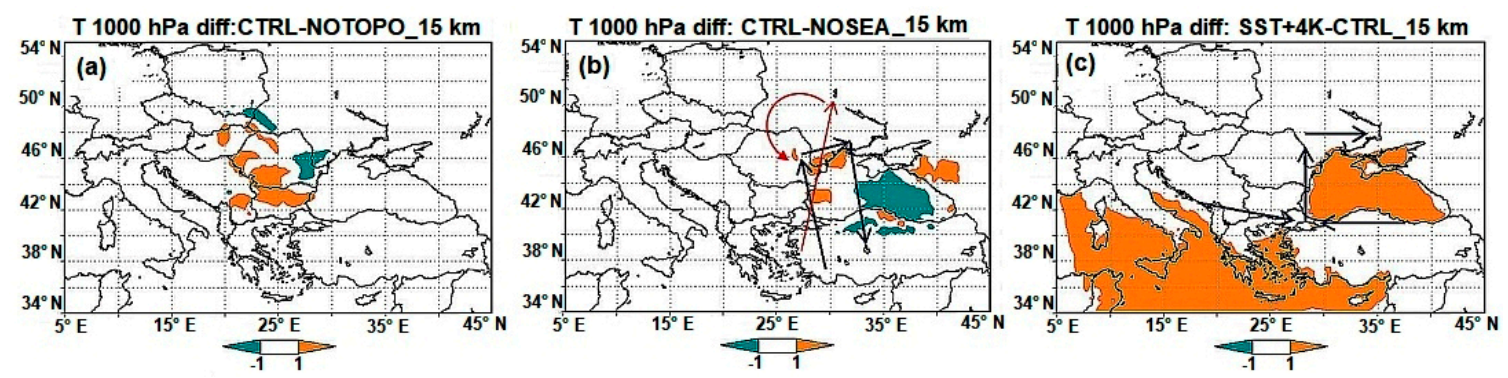

Figure 15. Difference of air temperature at $1000 \mathrm{hPa}$ (shaded as indicated on the color bar): (a) CTRL-NOTOPO, (b) CTRL-NOSEA (black arrows indicate cyclonic/anticyclonic pressure anomaly westwards/eastwards of the coast (seen in Figure 13d); also a cyclonic rotation (red curve) of the southwest-northeast advection (red arrow) results due to the presence of the Black Sea (see text); (c) SST+4K-CTRL. All are averaged from 06 UTC 20 April to 06 UTC 21 April 2017 (K). Note the large-regional signal of cyclonicity potential over the Carpathian basin generated by thermal wind when SST anomalies (Mediterranean and Black Sea) are positive (arrows in (c)).

\section{Event Climatology and Mechanism Validation over 40 Years}

\subsection{The Conceptual Model}

The mechanism of cyclogenesis and severe precipitation event relies on the interaction between the large-regional scale forcing. A summary of the key elements involved in this interaction mechanism is schematized in Figure 16. Large-scale conditions are: An unstable jet deep folding creating a strong thermal gradient and the presence of humidity (Mediterranean) advection sources, enhancing this gradient and the baroclinicity, through condensational latent heat, from surface to upper levels.

The mechanism of amplification involves the feedback between the strong baroclinicity area and the upper levels, leading to the occurrence of a mid-upper tropospheric secondary jet streak (Figures $7 \mathrm{~b}$ and $9 \mathrm{~b}$ ), which is not related to dynamical processes at the tropopause. The signature of a mid-level jet (MLJ) was also identified in satellite images [51] in 80\% of the extreme weather cases during 2004-2007 in southern Europe, in southwesterly flows. The analysis of the 20 April 2017 case emphasizes MLJ's upwards development up to $300 \mathrm{hPa}$ (Figure 9b), where an upper-level secondary jet streak (N-ULJ) is enhanced. The N-ULJ enhancement at $300 \mathrm{hPa}$ may involve this time the dynamical interaction of the condensational PV anomaly with the tropopause, as discussed in previous studies [52,53]. 
This analysis further emphasizes a key amplification mechanism that relies on N-ULJ-associated transverse ageostrophic circulation (this time the direct one, DC) interacting-under regional and local forcing-with the primary streak indirect circulation (IC). Regional forcing contributions come from topography-a flow-type modulated impact-the presence of the sea, and sea surface temperature. This interaction contributes to re-enhance the ascent and sustains the persistence of the event. Stronger transverse circulations enhance the low-level jets through southerly latent heat advection and strengthen further the ascent and condensation as a main contribution in this mechanism (Figure 16).

As shown, regional sources have contributions to both coupling of the circulations and strengthening of the LLJs. Since the NOSEA case shows a not-crossing jet IC-LLJ (required element for development, since otherwise the downwards IC branch would quickly damp it), it turns out that the presence of the sea is important to form and maintain the IC-LLJ. A warmer SST creates larger horizontal gradients shown to enhance far northwards and upwards the IC-LLJ and IC/DC interaction. Also, the topography contributes to enhance convergence and the IC-DC interaction, with a contribution expected to be flow-type-modulated. For regional forcings enabling enhanced IC/DC interactions, we showed a longer persistence of the surface pressure minimum. However this persistence is dominantly conditioned by the amount of condensational heat released.

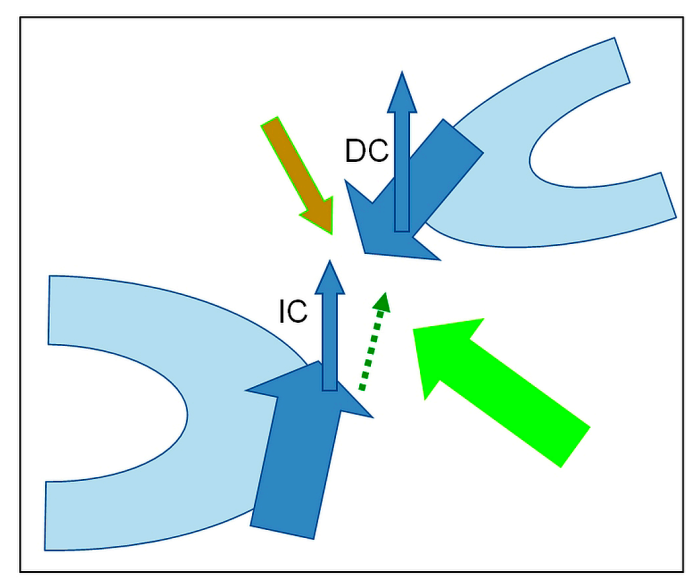

Figure 16. Schema of the mechanism: Jet streak (light blue), LLJs (dark blue), ageostrophic circulations (IC, DC, upward branches-blue thin arrows); humidity advection (dark green thin-lower levels, light green thick-upper levels); topographic forcing (brown).

\subsection{The Mechanism Validation}

To investigate the pre-conditions for the development of such events and to assess the robustness of the proposed mechanism, a climatology of these events was extracted from ERA-Interim analysis data over 40 years, between 1980 and 2019, for April, for the western Black Sea basin (west of $33^{\circ} \mathrm{E}$ ).

In this analysis, first, all the cyclones that crossed in April the western basin of the Black Sea were identified (pressure less than or equal to $1015 \mathrm{hPa}$ at the center). There were $80 \mathrm{in}$ total. Of these, only those that were associated with the presence of the $-5^{\circ} \mathrm{C}$ isotherm (at $850 \mathrm{hPa}$ level) over Romania (32 such situations) were identified, of which only 12 occurred after 15 April, and determined mixed precipitation or snowfall. Therefore, only $15 \%$ of the cyclones that crossed the western Black Sea basin were associated with the advection of cold air, under the conditions mentioned above, after 15 April. Mixed precipitation occurred in most of these cases, and only in four cases snowfall prevailed in eastern and/or southeastern Romania. Only two events were after 20 April, and the most intense and violent one in Moldavia (east Romania) was the one studied here, so it was an exceptional situation.

Stratified analyses were carried out on this event data basis. In the first layer entered all the 80 cyclones that evolved over the western basin of the Black Sea, the second stratification separated the 80 in 32 cyclones in which the $-5^{\circ} \mathrm{C}$ isotherm (at $850 \mathrm{hPa}$ level) was present over Romania, and 48 cases without this intense cold air advection (Table 2). The third stratification separated the cold 
cases in occluding or developing cyclones, and the last one separated each of these in events in which quantities of more than $25 \mathrm{~mm}$ and/or wind greater than $55 \mathrm{~km} / \mathrm{h}$ did (extreme events, criteria were similar to the case studied) and did not occur.

Each cluster was analyzed (mean of all cluster events) for temperature at $1000 \mathrm{hPa}$ (Figure 17), specific humidity (Figure 18), and wind at $300 \mathrm{hPa}$ (Figure 19), averaged over $24 \mathrm{~h}$ about the event.

Table 2. Stratification of late-spring cyclones over eastern Romania data basis (1980-2019).

\begin{tabular}{cclc}
\hline \multicolumn{2}{c}{ Cyclone Type } & \multicolumn{2}{c}{ Impact Type } \\
\hline \multirow{2}{*}{ Cold (32) } & Developing (17) & Extreme (9) & Non-extreme (8) \\
Warm (48) & Occluding (15) & Extreme (8) & Non-extreme (7) \\
& & Unstratified & \\
\hline
\end{tabular}

In Figure 17, it can be seen that the east Romania cyclones develop (Figure 17a-c) when the advection of cold air reaches southernmost latitudes, while occlusion cases (Figure 17d-f) correspond to a locking of the cold transport towards Romania at northern latitudes.

In addition, a defining feature for cyclones leading to extreme impact in eastern area, compared to those leading to below-average impact, is the direction of the northerly cold advection pointing toward northeast Romania, a requirement valid for both cold developing and occluding cases (Figure 17). This directional advection enhances the thermal gradient over the area, enabling conditions for wind intensification and higher precipitation amount in each of these classes.

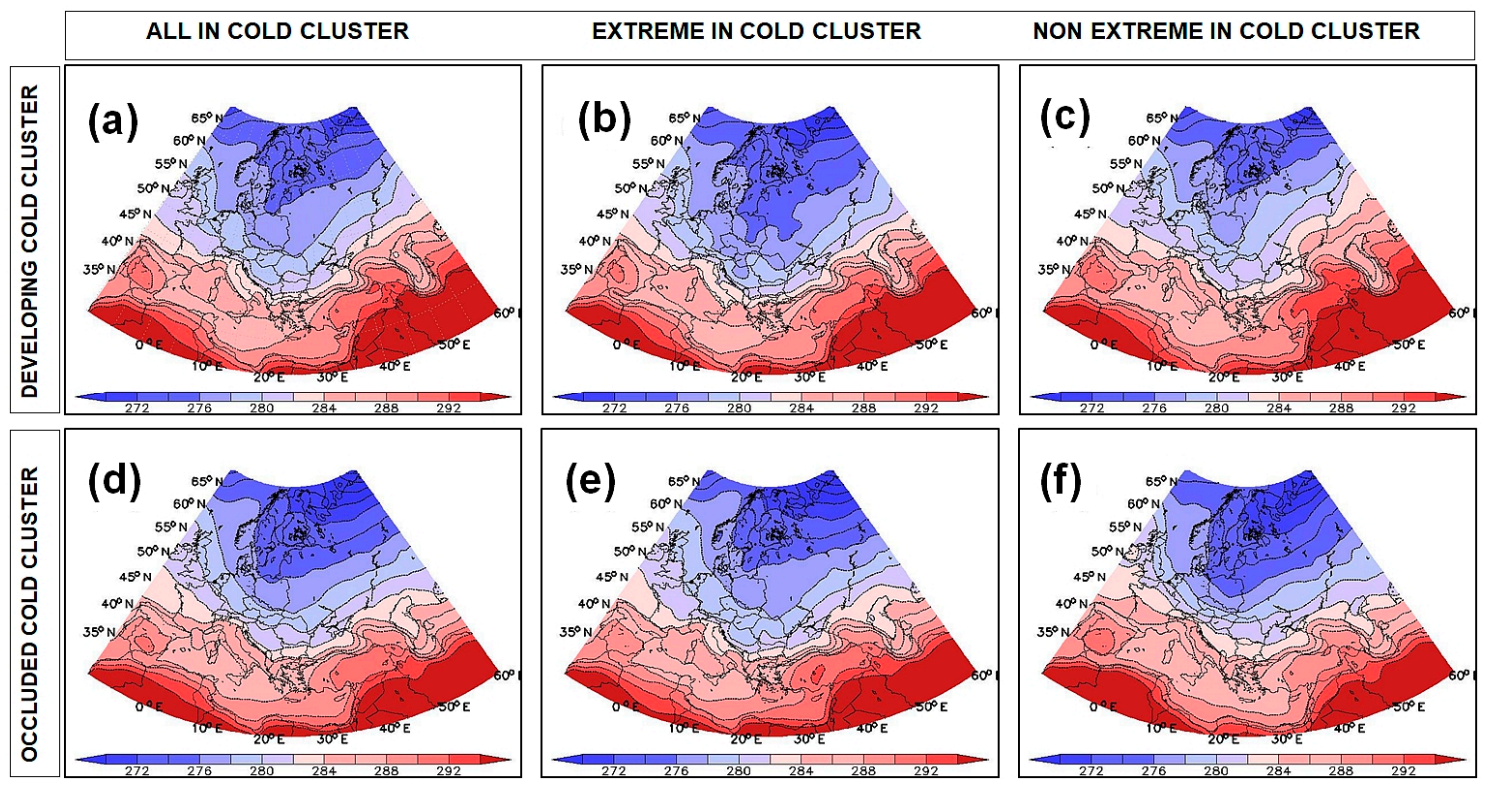

Figure 17. Stratification of cold events $(1000 \mathrm{hPa}$ temperature $(\mathrm{K}$, contour interval $2 \mathrm{~K})$ mean shaded as indicated on the color bar). Top: cold-developing (all) (a); cold-developing extreme (b); cold-developing below-average (c). Bottom: Cold-occluded (all) (d); cold-occluded extreme (e); cold-occluded below-average (f).

Regarding the moisture (Figure 18), it can be observed that the situations with significant southwesterly advection of humidity sourced over the central-eastern Mediterranean $\left[30^{\circ} \mathrm{N}-32^{\circ} \mathrm{N}\right.$, $\left.10^{\circ} \mathrm{E}-20^{\circ} \mathrm{E}\right]$ lead to developing cyclones (Figure 18a-c), while those with dryer air over this storm track source area for southeast Europe in April [54] result in occlusion (Figure 18d-f). Enhanced moisture over the Mediterranean source area is also required for extremes to occur; we note the extreme/non-extreme sub-classes are over/below average of the class's humidity amount in the area, and this feature is present for both developing and occluding classes for cold cases (Figure 18). 


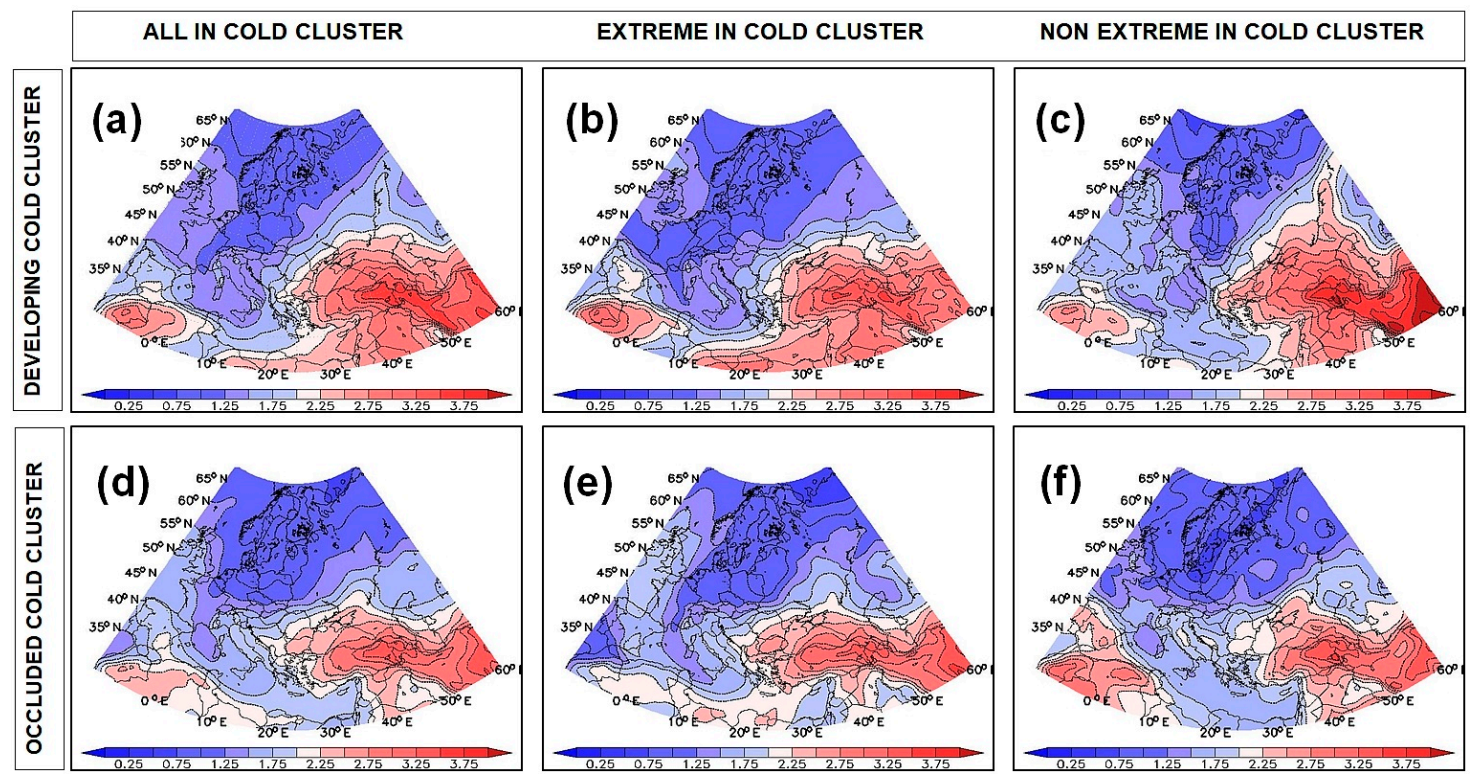

Figure 18. Same like Figure 17, but for $700 \mathrm{hPa}$ specific humidity $\left(\left(\mathrm{g} \mathrm{kg}^{-1}\right)\right.$, contour interval 0.25). Top: cold-developing (all) (a); cold-developing extreme (b); cold-developing below-average (c). Bottom: Cold-occluded (all) (d); cold-occluded extreme (e); cold-occluded below-average (f).

Figure 19 supports too the mechanism proposed concerning the ULJ. The presence of a southern jet stream is noted in all cases, required for east Romania April cyclogenesis. However while this remains on a west-east zonal transport over southeastern Europe in occluding cases, a sharper curved jet with a southwest-northeast flow is present in developing cases across the longitudes of interest. Moreover, the secondary jet streak in Eastern Europe (northeast Romania) is present (similarly to the case study) only in the extreme cases, with a stronger signature for developing cases. These sustain the idea of a secondary ageostrophic circulation's role required in order to significantly enhance ascent and amplify the local response.
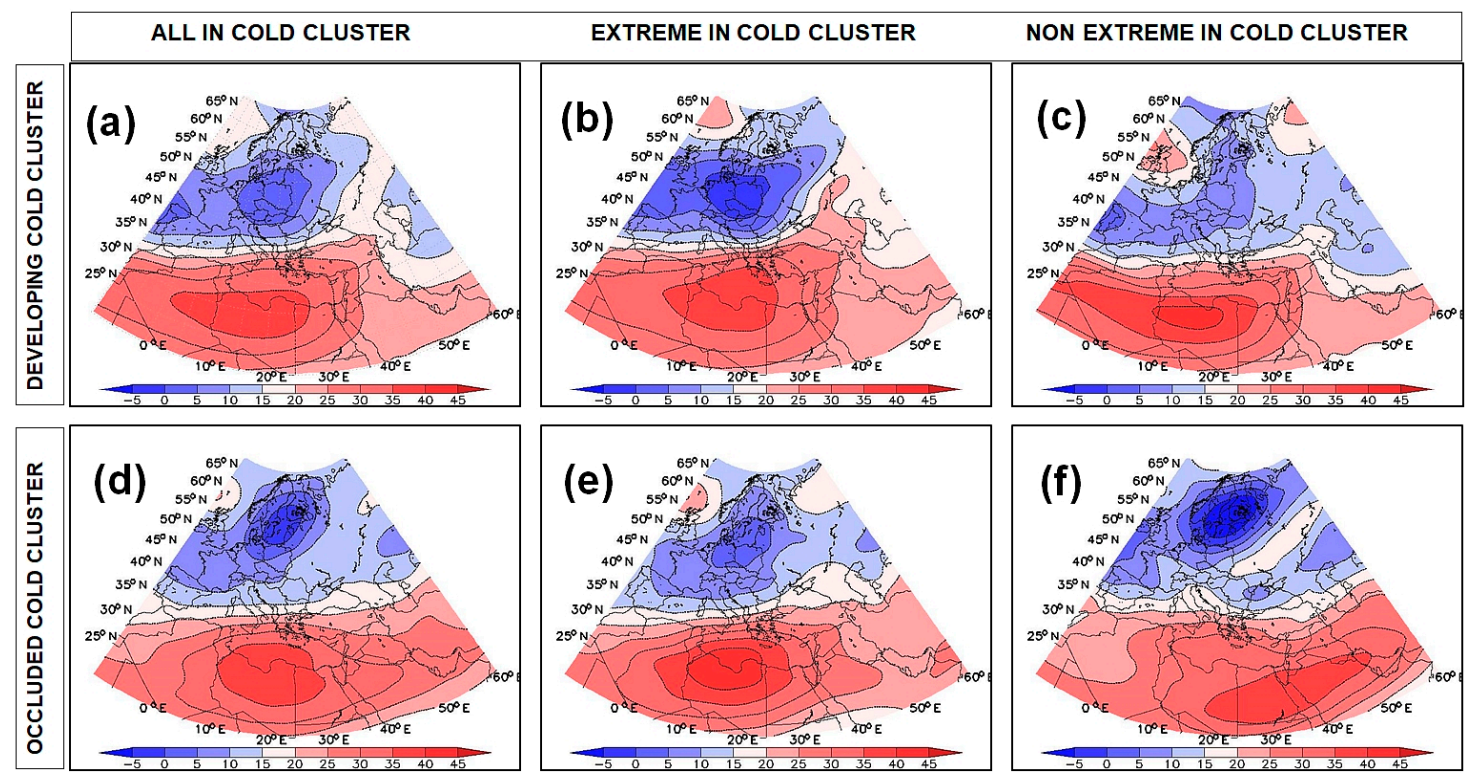

Figure 19. Same like Figure 17, but for $300 \mathrm{hPa} \mathrm{u}$ wind $((\mathrm{m} / \mathrm{s})$, contour interval $5 \mathrm{~m} / \mathrm{s})$. Top: cold-developing (all) (a); cold-developing extreme (b); cold-developing below-average (c). Bottom: Cold-occluded (all) (d); cold-occluded extreme (e); cold-occluded below-average (f). 
Hence, the main features of the development-cold advection southwards into the domain, significant east Mediterranean humidity advection sourcing southwesterly tracks, and ULJ streak split over the domain-are dominant and process-attributable (opposing features for development/occlusion) elements for process characterization. Their intensity directly scales with the intensity of the process and with the response in accumulated precipitation and wind.

\section{Conclusions}

In this study, we investigated the mechanism of development and the pre-conditioning at largeand local-scale of cyclones that are produced in the second half of the spring severe winter-type events over eastern Romania. These events have a major impact, especially on the crops of that year. The main processes involved were studied through sensitivity numerical simulations for the blizzard that occurred between 19 and 22 April 2017, the latest most severe blizzard (wind, precipitation, and material damage) in the eastern part of Romania for the last 40 years, and a mechanism of development was proposed.

Under initial conditions of large-scale forcing by an unstable jet with strong tropopause folding and by a pre-existent surface low in frontolitic evolution on an east Mediterranean-west Black Sea trajectory, the main focus was to identify the mechanism driving cyclone enhancement and further development leading to severe impact when reaching the western Black sea. Sensitivity experiments analyzed the contribution of large-regional scale interactions to this development. It is proposed that the mechanism of development into an extreme event is based on the generation of a secondary jet streak and ageostrophic (direct) circulation, through adiabatically-enhanced baroclinicity. Regional forcing acts then, towards the interaction and coupling of two formed transverse circulations (indirect and direct), enhance the ascent. Also, regional forcing acts to increase the baroclinicity through LLJ strengthening (e.g., warmer SST) and latent heat advection, enhanced by a stronger circulation. Third, these positive feedbacks of the low-level jet coupling act to enhance the persistence of the development.

Regarding the location and extent of the impacts, these were shown to be significantly influenced by the regional forcing. The sea surface temperature represents a slow forcing that drives an anticyclonic rotation and northwards advancement of the IC low-level jet and of associated impacts for warmer sea, due to the composed large-scale and coastal circulations. A southwards shift in impact location is expected due to the topography, impact modulated by the flow-type, with expected stronger shift under sub-critical Froude flow. These regional drivers can be potential indicators, supporting real-time forecasting of the impact localization that can be accounted for on updated observational data, when the model's SST or atmospheric parameters diverge from observations along the prediction time, or when multi-models spread along the forecast is significant.

The proposed development mechanism was analyzed on late-spring event climatology of the cyclones reaching the western Black Sea basin, extracted from Era-Interim data over the period 1980-2019. Conditions responsible for the cyclone development versus occlusion, and for increased versus low intensity of the response in wind and precipitation, were identified. At large scale, an unstable jet with sharp folding down to the lower troposphere enabling cold advection over the western area and significant moisture-advection availability (east Mediterranean sourced) are the main pre-conditions, shown to scale directly with both the developing and the impact's intensity. At regional scale, a particular feature of the extreme development is the secondary jet streak. Indeed, all developing, in opposite to occluding, and even more the developing cyclones associated with severe response events, show a secondary jet streak area, as required for a secondary (direct) ageostrophic circulation contribution to ascent. Over 40 years, the jet streak split is not existent in occluding cases, and it is significantly less emphasized for developing non-extreme cases.

Finally, we suggest that real-time updates on the observed drivers of the mechanism (synthesized in Figure 16) could enhance the prediction skill regarding the evolution of the development and the location, intensity, and persistence of the weather response. We also note that regional models 
capture well the mechanism and occurrence of these events, which gives confidence in analyzing their estimated changes in climate scenarios.

Forecasting winter-type phenomena occurring in middle-spring and estimating their future variability is very important because of their impacts. These can cause great economic damage, especially in agriculture, because the vegetation is already advanced at this time and the negative temperatures, snow, and frost significantly damage it. Defining weather proxies based on a conceptual model such as the one described here can add value to the direct model output. Based on satellite images, identifying the main elements-stratospheric dry PV intrusions, moisture advection, and the jet stream-and accounting for the SST and flow type, early appreciation on the development may be enabled to limit possible damages of severe events.

Author Contributions: Conceptualization, M.D.A. and M.C.; experimental design and methodology, M.C. and M.D.A.; software and modeling, M.C.; writing, M.D.A. (Sections 1, 2, 3.1, 4.1, 4.2 and 5) and M.C. (Sections 2, 3.1, 3.2, 4.1, 4.2 and 5).

Funding: The article was funded by the Romanian National Meteorological Administration (M.C. and M.D.A.) and by the Doctoral School of Physics, University of Bucharest (M.D.A.-Contract: 24005/F2/9).

Acknowledgments: The authors acknowledge the EUMETSAT/EUMeTrain for maintaining the ePort training tool, and the Romanian National Meteorological Administration for the data provided.

Conflicts of Interest: The authors declare no conflicts of interest.

\section{References}

1. Cazacioc, L. Spatial and Temporal Variability of Extreme Daily Precipitation Amounts in Romania. Rom. J. Meteorol. 2007, 9, 34-46.

2. Apostol, L. The Mediterranean Cyclones-the Role in Ensuring Water Resources and Their Potential of Climatic Risk, in the East of Romania. Present Environ. Sustain. Dev. 2008, 2, 143-163.

3. Vespremeanu-Stroe, A.; Cheval, S.; Tatui, F. The Wind Regime of Romania-Characteristics, Trends and North Atlantic Oscillation Influences/Regimul Vânturilor Din România-Caracteristici, Tendinte Si Influentele Oscilatiilor Nord-Atlantice. In Forum Geografic: Studii si Cercetari de Geografie si Protectia Mediului; University of Craiova, Department of Geography: Craiova, Romania, 2012; Volume 11, pp. 116-118.

4. Stefanescu, V.; Stefan, S.; Georgescu, F. Spatial Distribution of Heavy Precipitation Events in Romania between 1980 and 2009. Meteorol. Appl. 2014, 21, 684-694. [CrossRef]

5. Hustiu, M.C. The Risk of Blizzard Appearing in Barlad Plateau during 1981-2010. Revista Riscuri Si Catastrofe 2017, 20. [CrossRef]

6. Brâncuş, M.; Schultz, D.M.; Antonescu, B.; Dearden, C.; Ştefan, S. Origin of Strong Winds in an Explosive Mediterranean Extratropical Cyclone. Mon. Weather Rev. 2019, 147, 3649-3671. [CrossRef]

7. Trigo, I.F.; Bigg, G.R.; Davies, T.D. Climatology of Cyclogenesis Mechanisms in the Mediterranean. Mon. Weather Rev. 2002, 130, 549-569. [CrossRef]

8. Ion-Bordei, N.; Ion-Bordei, E. Fenomene Meteoclimatice Induse de Configuraţia Carpaţilor în Câmpia Română; Editura Academiei Române: Bucharest, Romania, 2008.

9. Georgescu, F.; Stefan, S. Cyclonic Activity over Romania in Connection with the Air Circulation Types. Rom. Rep. Phys. 2010, 62, 878-886.

10. Surkova, G.; Arkhipkin, V.; Kislov, A. Atmospheric Circulation and Storm Events in the Black Sea and Caspian Sea. Open Geosci. 2013, 5, 548-559. [CrossRef]

11. Georgescu, F.; Tascu, S.; Caian, M.; Banciu, D. A Severe Blizzard Event in Romania-A Case Study. Nat. Hazards Earth Syst. Sci. 2009, 9, 623-634. [CrossRef]

12. Ion-Bordei, E. Rolul Lanţului Alpino-Carpatic În Evoluţia Ciclonilor Mediteraneeni; Editura Printech: Bucharest, Romania, 2009.

13. Drăghici, I. Dinamica Atmosferei; Editura Tehnică: Bucharest, Romania, 1988.

14. Popa, F.; Soci, C. Méthode Classique et Actuelle d'analyse d'une Tempête de Neige. Revue Roumaine de Geographie 2002, 45, 77-186.

15. Cordoneanu, E. Particularităţi Ale Dinamicii Aerului Deasupra României; Editura Fundaţiei "România de Mâine": Bucharest, Romania, 2009. 
16. Georgescu, M. The First Severe Blizzard Episode of December 2009. Rom. J. Meteorol. 2010, 10, 13.

17. Danciu-Ciurlãu, D. An Episode of Late Blizzard, 25-26 March 2013. Present Environ. Sustain. Dev. 2014, 8, 165-174. [CrossRef]

18. Sandu, I.; Pescaru, V.; Poiana, I. Clima Romaniei; Editura Academiei Romane: Bucuresti, Romania, 2008.

19. Bălescu, O.I.; Beşleagă, N.N. Viscolele În Republica Populară Română; Institutul Meteorlogic: Bucharest, Romania, 1962.

20. Ciurlău, D. Climatological Landmarks of the Blizzard Phenomenon in the Bărăgan Plain Area. Aerul Si Apa Compon. Ale Mediu. 2014, 1, 461-468.

21. Manta, R.; Sfîcă, L.; Tişcovschi, A.; Constantin, D.; Mănoiu, V.; Radu, C. Late Snowfall and Blizzards in Moldavia, April 2017. Summary, Case of Study. Aerul. Si Apa Compon. Ale Mediu. 2018, 61-68. [CrossRef]

22. Bogdan, O.; Marinică, I. Hazarde Meteo-Climatice Din Zona Temperată: Factori Genetici şi Vulnerabilitate: Aplicaţii La România; Editura Universităţii “Lucian Blaga”: Sibiu, Romania, 2007.

23. Bojan, D. The Blizzard in the Zarand Land. Analele Univ. Din Oradea Ser. Geogr. 2008, 18, 81-85.

24. Costache, R.; Fontanine, I. The Snow Drift Potential in the Plain Area of Buzău County. Analele Univ. Din Oradea Ser. Geogr. 2013, 23, 245-254.

25. Manta, D.; Hustiu, M.; Sipos, Z. Agravating Factors in the Blizzard Situations in the South-East of Romania. Aerul Si Apa Compon. Ale Mediu. 2015, 446. [CrossRef]

26. Uccellini, L.W.; Kocin, P.J. The Interaction of Jet Streak Circulations during Heavy Snow Events along the East Coast of the United States. Weather 1987, 2, 289-308. [CrossRef]

27. Kumar, A.; Zhang, L.; Wang, W. Sea Surface Temperature-Precipitation Relationship in Different Reanalyses. Mon. Weather Rev. 2013, 141, 1118-1123. [CrossRef]

28. Dado, J.M.B.; Takahashi, H.G. Potential Impact of Sea Surface Temperature on Rainfall over the Western Philippines. Prog. Earth Planet. Sci. 2017, 4, 23. [CrossRef]

29. Llasat, M.-C.; Rigo, T.; Montes, J.-M. Orographic Role in the Temporal and Spatial Distribution of Precipitation. The Case of the Internal Basins of Catalonia (Spain). In Proceedings of the EGS Plinius Conference, Maratea, Italy, 14-16 October 1999; pp. 41-55.

30. Muhammad Tahir, K.; Yin, Y.; Wang, Y.; Babar, Z.A.; Yan, D. Impact Assessment of Orography on the Extreme Precipitation Event of July 2010 over Pakistan: A Numerical Study. Adv. Meteorol. 2015, 2015. [CrossRef]

31. Twardosz, R.; Cebulska, M.; Walanus, A. Anomalously Heavy Monthly and Seasonal Precipitation in the Polish Carpathian Mountains and Their Foreland during the Years 1881-2010. Appl. Clim. 2016, 126, 323-337. [CrossRef]

32. Dee, D.P.; Uppala, S.; Simmons, A.; Berrisford, P.; Poli, P.; Kobayashi, S.; Andrae, U.; Balmaseda, M.; Balsamo, G.; Bauer, D.P. The ERA-Interim Reanalysis: Configuration and Performance of the Data Assimilation System. Q. J. R. Meteorol. Soc. 2011, 137, 553-597. [CrossRef]

33. Giorgi, F.; Anyah, R. The Road towards RegCM4. Clim. Res. 2012, 52, 3-6. [CrossRef]

34. Elguindi, N.; Bi, X.; Giorgi, F.; Nagarajan, B.; Pal, J.; Solmon, F.; Rauscher, S.; Zakey, A.; O’Brien, T.; Nogherotto, R. Regional Climate Model RegCM: Reference Manual Version 4.5; Abdus Salam ICTP Trieste: Trieste, Italy, 2014.

35. Stoelinga, M.T. A Potential Vorticity-Based Study of the Role of Diabatic Heating and Friction in a Numerically Simulated Baroclinic Cyclone. Mon. Weather Rev. 1996, 124, 849-874. [CrossRef]

36. Romero, R.; Ramis, C.; Alonso, S. Numerical Simulation of an Extreme Rainfall Event in Catalonia: Role of Orography and Evaporation from the Sea. Q. J. R. Meteorol. Soc. 1997, 123, 537-559. [CrossRef]

37. Ahmadi-Givi, F.; Graig, G.; Plant, R. The Dynamics of a Midlatitude Cyclone with Very Strong Latent-heat Release. Q. J. R. Meteorol. Soc. 2004, 130, 295-323. [CrossRef]

38. Horvath, K.; Fita, L.; Romero, R.; Ivancan-Picek, B. A Numerical Study of the First Phase of a Deep Mediterranean Cyclone: Cyclogenesis in the Lee of the Atlas Mountains. Meteorol. Z. 2006, 15, 133-146. [CrossRef]

39. Persson, P.O.G.; Hare, J.; Nance, L.; Walter, B. Impact of Air-Sea Interaction on Extra-Tropical Cyclones. In Proceedings of the ECMWF Workshop on Ocean-Atmosphere Interactions, Berkshire, UK, 10-12 November 2008; pp. 123-146.

40. Pastor, F.; Gómez, I.; Estrela, M. Numerical Study of the October 2007 Flash Flood in the Valencia Region (Eastern Spain): The Role of Orography. Nat. Hazards Earth Syst. Sci. 2010, 10, 1331. [CrossRef] 
41. Messmer, M.; Gómez-Navarro, J.; Raible, C. Sensitivity Experiments on the Response of Vb Cyclones to Sea Surface Temperature and Soil Moisture Changes. Earth Syst. Dyn. 2017, 8, 477-493. [CrossRef]

42. Kim, K.-Y.; Lee, S.; Kim, M.-K.; Cho, C.-H. Long-Term Variability of Cold Surges in Korea. Asia-Pac. J. Atmos. Sci. 2014, 50, 519-529. [CrossRef]

43. Park, T.-W.; Ho, C.-H.; Jeong, J.-H.; Heo, J.-W.; Deng, Y. A New Dynamical Index for Classification of Cold Surge Types over East Asia. Clim. Dyn. 2015, 45, 2469-2484. [CrossRef]

44. Lensky, I.; Rosenfeld, D. Clouds-Aerosols-Precipitation Satellite Analysis Tool (CAPSAT). Atmos. Chem. Phys. 2008, 8, 6739-6753. [CrossRef]

45. Hoskins, B.J.; McIntyre, M.E.; Robertson, A.W. On the Use and Significance of Isentropic Potential Vorticity Maps. Q. J. R. Meteorol. Soc. 1985, 111, 877-946. [CrossRef]

46. Lackmann, G. Midlatitude Synoptic Meteorology, Cdr Edition; American Meteorological Society: Boston, MA, USA, 2011.

47. Martin, J.E. Mid-Latitude Atmospheric Dynamics: A First Course; John Wiley \& Sons: Hoboken, NJ, USA, 2013.

48. Vaughan, G.; Antonescu, B.; Schultz, D.M.; Dearden, C. Invigoration and Capping of a Convective Rainband Ahead of a Potential Vorticity Anomaly. Mon. Weather Rev. 2017, 145, 2093-2117. [CrossRef]

49. Henri, C. Device for Deflecting a Stream of Elastic Fluid Projected into an Elastic Fluid. U.S. Patent No. 2,052,869, 1 September 1936.

50. Munson, B.R.; Young, D.F.; Okiishi, T.H. Instructor's Manual to Accompany Fundamentals of Fluid Mechanics; Wiley: Hoboken, NJ, USA, 1990.

51. Georgiev, C.G.; Santurette, P. Mid-Level Jet in Intense Convective Environment as Seen in the $7.3 \mathrm{~m}$ Satellite Imagery. Atmos. Res. 2009, 93, 277-285. [CrossRef]

52. Wernli, H.; Dirren, S.; Liniger, M.A.; Zillig, M. Dynamical Aspects of the Life Cycle of the Winter Storm 'Lothar' (24-26 December 1999). Q. J. R. Meteorol. Soc. 2002, 128, 405-429. [CrossRef]

53. Agustí-Panareda, A.; Thorncroft, C.; Craig, G.; Gray, S. The Extratropical Transition of Hurricane Irene: A Potential-vorticity Perspective. Q. J. R. Meteorol. Soc. 2004, 130, 1047-1074. [CrossRef]

54. Flocas, H.A.; Simmonds, I.; Kouroutzoglou, J.; Keay, K.; Hatzaki, M.; Bricolas, V.; Asimakopoulos, D. On Cyclonic Tracks over the Eastern Mediterranean. J. Clim. 2010, 23, 5243-5257. [CrossRef]

(C) 2019 by the authors. Licensee MDPI, Basel, Switzerland. This article is an open access article distributed under the terms and conditions of the Creative Commons Attribution (CC BY) license (http://creativecommons.org/licenses/by/4.0/). 